\title{
Privatization in the United States
}

\section{Citation}

Lopez-de-Silanes, Florencio, Andrei Shleifer, and Robert W Vishny. 1997. Privatization in the United States. Rand Journal of Economics 28, no. 3: 447-471

\section{Published Version}

https://editorialexpress.com/cgi-bin/rje_online.cgi?

action=view \&year $=1997 \&$ issue $=$ aut $\&$ page $=447 \& \&$ tid $=152740 \& s c=1$ UVkp $6 \mathrm{pt}$

\section{Permanent link}

http://nrs.harvard.edu/urn-3:HUL.InstRepos:30727606

\section{Terms of Use}

This article was downloaded from Harvard University's DASH repository, and is made available under the terms and conditions applicable to Other Posted Material, as set forth at http:// nrs.harvard.edu/urn-3:HUL.InstRepos:dash.current.terms-of-use\#LAA

\section{Share Your Story}

The Harvard community has made this article openly available.

Please share how this access benefits you. Submit a story.

Accessibility 
NBER WORKING PAPER SERIES

\title{
PRIVATIZATION IN THE UNITED STATES
}

\author{
Florencio López-de-Silanes \\ Andrei Shleifer \\ Robert W. Vishny
}

Working Paper No. 5113

\author{
NATIONAL BUREAU OF ECONOMIC RESEARCH \\ 1050 Massachusetts Avenue \\ Cambridge, MA 02138 \\ May 1995
}

The authors are grateful to Mark Duggan for excellent research assistance, to Joshua Angrist, Suzanne Cooper, Oliver Hart, James Hines, Caroline Hoxby, Guido Imbens, Anne Piehl, James Poterba, and especially Larry Katz for many comments, and to the National Science Foundation and Harvard Institute for International Development for research support. This paper is part of NBER's research programs in Corporate Finance and Public Economics. Any opinions expressed are those of the authors and not those of the National Bureau of Economic Research.

(C) 1995 by Florencio López-de-Silanes, Andrei Shleifer and Robert W. Vishny. All rights reserved. Short sections of text, not to exceed two paragraphs, may be quoted without explicit permission provided that full credit, including $\odot$ notice, is given to the source. 
NBER Working Paper \#5113

May 1995

\title{
PRIVATIZATION IN THE \\ UNITED STATES
}

\begin{abstract}
In the United States, the two principal modes of producing local government services are inhouse provision by government employees and contracting out to private suppliers, also known as privatization. We examine empirically how United States counties choose their mode of providing services. The evidence indicates that state clean-government laws and state laws restricting county spending encourage privatization, whereas strong public unions discourage it. The evidence is inconsistent with the view that efficiency considerations alone govern the provision mode, and points to the important roles played by political patronage and taxpayer resistance to government spending in the privatization decision.
\end{abstract}

Florencio López-de-Silanes

Kennedy School of Government

Harvard University

Cambridge, MA 02138
Andrei Shleifer

Department of Economics

Harvard University

Cambridge, MA 02138

and NBER

Robert W. Vishny

Graduate School of Business

University of Chicago

Chicago, IL 60637

and NBER 
I. Introduction.

In the United States, privatization mainly refers to the contracting out by the government of local public services to private providers. A city or county government may contract with a private company to pick up garbage, to keep city parks clean, to manage its hospitals, to provide ambulance services, to run schools and airports, or even to provide police and fire protection. In the last 25 years, this method of providing public services has become more popular, although it is still less common than inhouse provision of public services by city or county employees. Nonetheless, the growth of the private provision of public services has stimulated a lively discussion of the wisdom of contracting by the government.

The main argument for contracting is the accumulating evidence that it usually saves local governments money, and sometimes a lot of money, relative to public provision (see Savas 1982, 1987, National Commission for Employment Policy 1988, ICMA 1989, Donahue 1989, Kemp 1991). The principal reasons for this are that private contractors use fewer people than governments do to provide the same service (Savas 1987), pay 10 to 20 percent lower wages, and offer employee benefits that are sometimes orders of magnitude lower than those in the government (Stevens 1984). In Los Angeles county, one of the leaders in contracting out, the average service cost reduction achieved from contracting has been around 36 percent, giving the county in 1988 an estimated savings of $\$ 133$ million (National Commission for Employment Policy 1988).

This evidence raises the obvious question: why does private contracting remain much less popular than inhouse provision? Why aren't more of local government services privatized? In this paper, we try to examine the determinants of the decision to contract out or provide services inhouse.

To this end, we examine three types of potential determinants of the provision mode: efficiency (social goals), political patronage, and ideology. The efficiency view suggests that the government can sometimes deliver services that better address social goals if the provision is carried out by its own 
employees, because politicians and civil servants place more weight on these goals than do the private contractors. Such attention to social goals is in some cases efficient despite the higher cost of inhouse provision. The political patronage view argues that politicians get political support from public employees when services are provided inhouse, and hence favor this mode unless pressured into lower cost private contracting by taxpayers. The ideology view states that some voters simply hate big government, and so support privatization.

In this paper, we empirically examine the merits of these three views of the determinants of privatization using a sample of public services for the 3042 United States counties. We have little direct evidence on the efficiency view, hut try instead to find evidence hearing on the political patronage view, and to a lesser extent on the ideology view. Specifically, we explore the fundamental tradeoff between the political henefits of inhouse provision and the pressure to curb government spending?.

We examine a range of services that counties most commonly provide, including hospitals, landfills, libraries, nursing homes, public transit, sewerage, stadiums, fire protection, airports, water supply, electric utility, and gas utility, and look at two modes of provision of these services: contracting and inhouse. We do not look at the less common alternatives to public provision, such as volunteerism, franchising, or vouchers, which are also sometimes described as privatization (Savas 1987). Since different services are provided hy different levels of government, in most cases only a small subset of the counties provide a given service at all. We do not focus on the alternative of non-provision, also known as service-shedding, in this paper.

We look at the determinants of the provision mode in 1987, and at how it changes from 1987 and 1992. To do that, we look at a variety of political and budgetary variables, focusing primarily on state laws that influence the political benefits and costs of inhouse provision by the counties. For example,

${ }^{2}$ Kodrzycki (1994) looks at some of the demographic and labor market determinants of the privatization decision. She does not examine the political issues that are the focus of our paper. 
some states require a merit system in county hiring, set local purchasing standards (such as requirement of competitive bidding), forbid political activity by public employees, etc. Under the political patronage model, these laws should reduce the county politicians' discretion and hence reduce the political benefits obtainable from hiring government employees to provide services. This, in turn, should raise the likelihood of privatization.

Along similar lines, the main benefits of inhouse provision accrue to public employees, who are also the greatest opponents of privatization. We use a variety of labor market and unionization measures to gauge their role in determining the provision mode.

Under the political patronage model, harder budget constraints of local governments raise the likelihood of privatization. We focus on the role of state laws, such as restrictions on bond issues, balanced budget amendments, and restrictions on taxation by counties. In addition, following Poterba (1994), we look at state fiscal crises as stimuli to privatization. These enable us to test empirically the critical question of how political patronage becomes constrained by the pressures from taxpayers.

The next section briefly outlines the three theories of privatization and their predictions. Section III describes our data set. Section IV presents the basic evidence on the determinants of privatization and deals with some econometric problems. Section V concludes.

\section{Theoretical Issues.}

The three leading theories of the determinants of the privatization decision -- efficiency (social goals), political patronage and ideology -- have different implications for the data. Our empirical analysis focuses on the effects of clean government and hard budget constraint laws on privatization decisions. Accordingly, we evaluate the predictions of the three theories for the effects of these laws.

Some of the reasons for inhouse provision of government services are purely normative. Private contractors might fail to pursue social goals that politicians want to attain (see Sappington and Stiglitz 
1987, Shapiro and Willig 1990). If these politicians cannot write a complete contract that specifies exactly what contractors are supposed to do in all circumstances, they need a public hureaucracy they can control better to make sure these goals are achieved ${ }^{3}$. For example, private providers of health care might turn down the sickest patients to avoid incurring the high cost of treating them if they can find a reason within the contract to do so. A publicly run hospital, in contrast, would he more likely to accept such patients, especially if politicians ask it. Similarly, it may not be efficient for a government to contract out the imprisonment of dangerous criminals. The contractor might abuse the criminals, or reduce security in the prison, to cut costs. The government may be unable to specify in the contract all the actions that must be taken to ensure the safety and the security of the prisoners, but if it asks for changes after the contract is signed, the contractor can refuse unless the terms are improved. More generally, private providers might cut quality if they don't care about repeat husiness and if quality levels are not fully specified in the contract.

These examples suggest that incomplete contracts can give the contractor an opportunity to shirk, as well as the power to hold up the government that wants to correct the shirking. To avoid these costs if opportunism, the government might choose to hire its own employees to provide the service. Surely, such employees can still shirk, but then politicians can order them to improve without being blackmailed into paying extra. As in Grossman and Hart (1986), politicians have more power over employees than over private contractors. The problem of excessive contractor power, incidentally, becomes much more severe if the politicians writing the contract with the private suppliers make a mistake (forget to include performance measures in the contract) or are simply bribed to write a contract that henefits the private supplier (AFSCME, 1984).

The above discussion suggests some potential efficiency benefits of inhouse provision of

\footnotetext{
${ }^{3} \mathrm{Hart}$, Shleifer and Vishny (1995?) discuss the importance of incomplete contracts in determining whether a service provision should be public or private.
} 
government services. Of course, there may be efficiency benefits of private contracting as well, such as contractor specialization and investment in specific assets. In equilibrium, both delivery modes will be observed.

If efficiency considerations alone determined the provision mode, there would be no correlation between clean government laws and privatization. After all, under the efficiency model, politicians have no objectives other than public welfare, and hence clean government laws should have no effect on their actions. The efficiency model would, however, predict that hard budget constraint laws increase the likelihood of privatization. A poorer government is less likely to care about the uncontractible aspects of prison security, or the assurance of high quality health care. It would also be more interested in cost savings that contractors can obtain.

The normative arguments for public provision, however, are probably not the whole story. Even in the areas where private contracting is relatively common, and no persuasive arguments about excessive power can be made (e.g. garbage collection or park maintenance), we still observe the dominance of inhouse provision. This suggests that positive rather than normative arguments need to be used to explain the scope of inhouse provision.

Specifically, local politicians might choose to provide services inhouse because they derive political benefits from such provision, including the support of local public sector unions, opportunity to purchase supplies from political allies, ability to hire relatives and campaign activists, ability to use local government employees on political projects etc. It is more difficult to derive all these benefits from private contractors, since the politician loses a large measure of control once the contract is signed. Boycko, Shleifer and Vishny (1994) and Shleifer and Vishny (1994) have argued that the pursuit of political benefits is the principal reason for the pervasive political control over firms around the world".

The existing literature on contracting recognizes the pivotal role of political factors as well. In

${ }^{4}$ The arguments in these papers are related to Stigler's (1971) capture theory of regulation. 
the United States, the main political factor favoring inhouse provision is the clout of public employee unions, which have emerged as the strongest opponents of privatization ${ }^{5}$ (see the readings in Kemp 1991, AFSCME 1984, Kodrizycki 1994). Politicians seek to win the support of these unions, which are the major beneficiaries of inhouse provision, or at least avoid their active opposition. If politicians could use public provision of services to pursue their goals without a budget constraint, they would keep everything public $^{6}$. The pressure for privatization must come from voters preference for lower taxes, which leads to lower public budgets and hence makes inhouse provision less affordable. Indeed, the hardening budget constraints of local governments are often mentioned as the main stimulus for privatization (Savas 1987, Kemp 1991).

The political model has clear empirical implications. Clean government laws reduce the political benefits of inhouse provision, since they restrict politicians' freedom of action, and hence make privatization more likely. Hard budget constraint laws make it more difficult for politicians to spend public money to procure political benefits, and hence encourage privatization.

The third theory stresses the importance of voters' ideology. It is hard to imagine that voters have preferences over something as technical as the mode of delivery of government services, but voters surely have views about the government more generally. It is possible, therefore, that privatization, clean government and budgetary-limit laws are simultaneously determined by the degree of voters' antigovernment sentiment.

To evaluate this view, we control for voting patterns (republican vs. democrat) in different counties. We also look at correlations between voting patterns and the presence of various clean government and budgetary-limits laws on the states' books, as well as the correlations among the laws

${ }^{5}$ López-de-Silanes (1994) describes the role of unions in opposing privatization in Mexico.

${ }^{6}$ Unless they prefer to collect bribes and political contributions from potential contractors to winning votes from the beneficiaries of public provision. In the United States local elections, seeking voter support through patronage is probably more important. 
themselves. This evidence could give us an indication of whether a single factor called anti-government sentiment can simultaneously explain voting patterns and restrictive state laws.

III. Data.

\section{The Mode of Provision}

The analysis of this paper is hased on the 1987 and 1992 Censuses of Governments, which surveyed all 3,042 counties in the United States. The 1987 Census collected information about the following twelve services: airports, water supply, electric utility, gas supply, hospitals, landfills (dumps), libraries, nursing homes, public transit, sewage system, stadiums/convention centers and fire protection. The key question was whether a county a) provided and operated a service, b) provided and contracted out a service, or c) neither of these. Not every service is provided by every county, since many services are often provided by townships, municipalities or even states. Moreover, there are several additional modes of providing services, including totally private provision (individuals pay private vendors), franchise agreements, grants/subsidies to private suppliers, vouchers to consumers who buy from private suppliers, volunteers, and self-help. In the 1987 Census of Governments, these alternative, but much less frequent, modes of paying for public services are grouped together with non-provision. Our analysis therefore focuses only on those observations where the county provided a service either inhouse or through a private contract.

The 1992 Census of Governments asked about five additional services, namely refuse collection, ambulances, maintenance of streets and highways, industrial development and resource recovery/recycling. Some of these services, such as refuse collection, are often provided hy counties, and it is peculiar that they were not asked about in 1987. The 1992 Census also distinguished between contracting out when the county owned the capital and contracting out when the contractor did. The 1992 Census continued to group together non-provision and provision through a method other than contract 
or inhouse supply. As of this writing, the 1992 Census has not been completed. We have the data on the mode of provision in 1992, but not on many of the explanatory variables. For this reason, we focus on 1987 cross-section, as well as on switches from 1987 to 1992.

Table 1 presents some of the basic information on the mode of provision of the twelve services that were asked about in both 1987 and 1992 . Some services are provided by a lot of counties, including libraries (42.9 percent), landfills (52.1 percent), or airports (27.5 percent). Others, such as gas and electric utilities, are hardly ever provided at a county level. Altogether, less than 20 percent of the possible county-service combinations are actually provided either inhouse or by contract, giving us a total of 7,185 county-service observations. In 1987 , there are roughly three times as many cases of inhouse provision than of contracts. Libraries are hardly ever contracted out, but utilities almost always are, whereas hospitals and airports are contracted out about half as often as they are managed inhouse. Overall, contracting out appears to be a significant, but still relatively small, mode of provision of public services.

The right panel of Table 1 presents the same information for 1992. The incidence of county provision of services increases by almost 15 percent, so there are a total of 8,243 county-service pairs in 1992, or 22.6 percent of the feasible universe. Landfills, libraries, fire protection, and airports remain the most popular. Interestingly, inhouse provision is now less than twice (as opposed to three times in 1987) more common than contracting. The reason for that can be gleaned from Table 2 , which examines the switching of observations from 1987 to 1992 . Table 2 shows that relative to the available universe, there has been much less privatization than nationalization between 1987 and 1992 . Contracted out services had a higher likelihood of being brought inhouse ( 363 out of 1,697$)$ than county government provided services had of being contracted out $(533$ out of 5,488$)$. There is no wave of privatization of county-provided services in this sample.

Table 2 also shows, however, that when counties started to provide services they did not provide 
before, they were fifty percent more likely to provide them through contract. Of these newly provided services, 1,150 were delivered by the county government, and 1,662 were delivered by private contractors. This is especially noteworthy since overall contracting remains relatively less common than inhouse provision. The much higher incidence of private contracting in the provision of new county services accounts for the greater overall prevalence of contracting in 1992 than in 1987 . These results, are understandable if public sector unions are effective opponents of privatization, but are not organized enough to stop private provision of services not currently provided by public employees. Later in the paper, we return to the question of changes in provision mode hetween 1987 and 1992, but first we focus on the 1987 cross-section.

\section{Political Variables}

The principal hypothesis of this paper is that the more difficult it is to pursue political ends through inhouse provision of public services, the more likely are local politicians to privatize these services. To measure political benefits of inhouse provision, we rely primarily on variation in state "clean government" laws. Our source of data on these variables is a compilation of State Laws Governing Local Government Structure and Administration from the U.S. Advisory Commission on Intergovernmental Relations (ACIR, 1993). Since local governments in the U.S. are legally created by the states, they are established in accordance with state constitutions and statutes. All states therefore decide how much authority can be exercised by each type of government. We use information collected by ACIR for 1990 for all U.S. states regarding four "clean government" measures (ACIR, 1993). These are all the measures from ACIR that we thought could be reasonably interpreted as conducive to privatization.

First, we use a dummy for whether state law requires its counties to use a merit system in hiring. Presumably, a merit system makes it more difficult for politicians to hire relatives, friends, and campaign 
activists for government posts, and therefore makes inhouse provision less attractive. Shleifer and Vishny (1994) have conjectured in the context of West European privatizations that a strong civil service might encourage politicians to divest state firms since they are less able to control these firms and staff them with political allies.

Second, we use a dummy for whether state law sets local purchasing standards for its counties. Generally, a local purchasing standard requires counties to use competitive bidding on all purchases over a specified amount, or on all purchases of a designated type. As a result, a local purchasing standard makes it less attractive to use inhouse providers of services to favor politically desirable suppliers. In this way, a local purchasing standard might promote privatization. A local purchasing standard, however, might also sometimes make corrupt contracting with allies of politicians more difficult, which would favor inhouse provision over privatization. The interpretation of this variable, therefore, is ambiguous.

Third, we use a dummy for whether the state law forbids political activity by government employees. If the state law forbids such activity, then hiring government employees becomes less attractive, and hence contracting becomes more attractive relative to inhouse provision.

Fourth, we use a dummy for whether state law allows county employees to strike. This variable is a bit difficult to interpret. On the one hand, if public employees can strike, then they can presumably hargain for higher wages, which makes them more expensive to employ and hence makes privatization more attractive. On the other hand, holding relative wages of public employees constant as we do in the regression, the ability to strike enables public employees to resist privatization through strikes, which makes privatization more costly. In fact, one of the consistent findings of the earlier literature on local government contracting is that strong public sector unions often succeed in blocking privatization. Since we are holding wages constant, we expect that the ability to strike is a deterrent to contracting out ${ }^{7}$.

\footnotetext{
${ }^{7}$ The prohibition on strikes by public employees could obviously be considered not just as a clean government variable, but also as a labor market conditions variable (see below).
} 
To capture the ideological attitudes to government, we consider the fraction of votes in the county for a republican gubernatorial candidate in the election closest to 1987 (Inter-University Consortium for Political and Social Research, General Election Data for the United States, 1970-1988). When more people vote republican, the local government should be more likely to privatize.

\section{Labor Market Conditions}

We argued that patronage is a key benefit of inhouse provision of public services. But patronage is also an important cost of inhouse provision, since hiring potential political supporters at high wages is also expensive, and irritating to the electorate. As a result, the predictions of the effects of labor market conditions on privatization are sometimes ambiguous. Nonetheless, these variables are very important to include in the analysis.

First, we consider each county's civilian unemployment rate in 1986 (from Bureau of Census, County Statistics file 3). Since public hiring is often viewed as a politically desirable solution to unemployment problems, a higher unemployment rate should make privatization less attractive.

Second, we consider the public employee wage premium, defined as the ratio of the average annual pay for a full-time equivalent county employee to the average annual pay for a full-time equivalent private sector employee in that county (from 1987 Census of Governments, Employment Statistics and 1987 County Business Patterns, respectively). The mean of this ratio in our sample is 1.15. Many observers believe that the greatest difference in public and private pay is not in wages, but in benefits, and the number we compute ignores benefits. Whether high relative pay should encourage or discourage privatization is ambiguous. A higher public wage premium should foster stronger support for politicians who deliver it, and hence discourage privatization, but it also raises the cost of inhouse provision relative to contracting out. We control for the wage premium in the regressions without a strong theoretical prior about its effect. 
Third, we consider the fraction of county government workers in unions (from 1987 Census of Governments, Employment Statistics). This variable is similarly interpretable as the state law allowing strikes. A higher union participation by county employees might encourage privatization because it raises costs. However, holding wages constant, higher union participation probably deters privatization by raising the effectiveness of public employees in resisting contracting out.

Fourth, we look at the number of county government employees per 1000 people (from 1987 Census of Governments, Employment Statistics). In a cross-section, a higher density of public employment is almost by definition negatively associated with privatization, and therefore we do not include this variable in the cross-sectional analysis. This variable is however useful for looking at switchers between 1987 and 1992. A higher incidence of public employment may encourage privatization as a way to save costs, but may also make opposition to privatization more powerful. The sign on this variable must therefore be determined empirically.

\section{Budget Constraints}

We have interpreted the state laws and the labor market variables largely in terms of political benefits of inhouse provision. But politicians cannot spend on such benefits, or even on socially desirable activities, without limit because their budgets are limited. The harder the budget constraints politicians face, the more likely they should be to privatize government services. As hefore, our preferred measures of hard budget constraints are state laws limiting a county's ability to tax and to spend. These measures are preferred to county cash flow measures, which are endogenous. For example, if we found that large budget deficits are associated with more inhouse provision, it could be that counties providing services inhouse spend more and therefore run larger deficits, or it could be that the ability to run a deficit deters privatization. To have a clearer interpretation, we focus mainly on state laws.

We have five such state law variables, all as before derived from ACIR (1993). The first is a 
dummy equal to one if the state allows its counties to engage in short-term horrowing. We conjecture that such an ability softens the budget constraint, and hence fosters inhouse provision. The second is a dummy equal to one if the state imposes deht limits on counties, which can be expressed as a percentage of assessed property value, or in ahsolute terms, or in some other way. We conjecture that such limits harden budget constraints, and hence promote privatization. The third variable is a dummy equal to one if state law mandates a balanced budget for counties. Presumably, such mandates harden budget constraints and encourage contracting out. The fourth variable is a dummy equal to one if state takeover of county finances is possible by state law. This possibility of a bailout by the state should soften the budget constraint, and hence make privatization less likely. The fifth variable we use is a dummy equal to one if the state assesses county property taxes. Such limits on discretionary taxation by county politicians should harden budget constraints, and thus encourage privatization.

Our last soft budget constraint variable is a state-level cash flow variable motivated in part hy Poterba's (1994) analysis of state fiscal crises. All states have so-called rainy day funds, which are funds that states have in reserve that can be made available for unforeseen circumstances. We use the amount of money in each state's rainy day fund at the end of 1987 relative to each state's total government expenditure in that year. Presumably, the less money there is in such an emergency fund, the less financially secure the counties in the state are, and hence the more likely is privatization. This variable is of particular interest in addressing the question of whether fiscal emergencies trigger privatization, and hence is most useful in the analysis of switchers between 1987 and 1992.

\section{Control Variables}

In our empirical analysis, we want to minimize the likelihood that our results capture some unobserved state or county heterogeneity. As a precaution, therefore, we try to control for several county and state characteristics. In our analysis, we control for each county's 1987 population, 
population per square mile of land, county per capita income, county per capita hank deposits, and fraction of county population above 25 years old with at least a high school degree (all from Bureau of the Census, County Statistics file 4, and Census of Population and Housing). These are just the standard demographic, income, and wealth measures. We also add a dummy equal to 1 if a county belongs to a Regional Organization, which tend to be collaborations hetween local governments sometimes used for jointly providing or purchasing public services (1987 Census of Governments, Government Organization file). Lastly at the county level, we control for the fraction of county population living in municipalities in 1987, since municipalities like counties often provide public services. In addition, we control for state resident population in 1987 , bank deposits per capita in the state in 1987 , personal per capita income in the state in 1987, state unemployment in 1986, and fraction of the state's population with at least a high school degree (County Business Patterns and Bureau of the Census, County Statistics file 4, Census of Population and Housing). Since we use state level variation for many of our explanatory variables, including these state controls in addition to county controls is essential.

IV. Results.

The analysis in this section is divided in four parts. First, we present the basic cross-sectional results on the determinants of the provision mode using conditional means of the dependent variables, a probit and a linear regression. Second, we deal with two statistical issues that the basic results do not deal with: sample selection bias and potential correlation among the residuals. Third, we interpret the evidence, and in particular attempt to distinguish the political patronage model from the ideology model. Fourth, we present the results on the switchers in provision mode between 1987 and 1992.

\section{$\underline{\text { Basic results }}$}

Table 3 presents conditional means of the privatization variables as a function of each of the main 
determinants of privatization discussed above. The unit of observation is county-service, so for some counties we have several observations. We do not include the observations where the county does not provide a service, or provides it via a third way. In this sample, 23.6 percent of county-services were provided through contract, and 76.4 percent inhouse.

The results on the 1987 cross-section are suggestive. Merit system laws, purchasing standards laws, prohibitions against political activity by public employees and against public employee strikes all encourage privatization. The results on labor market variables are more mixed, but high unionization seems to discourage privatization. Softening county budget constraints, through allowance of county short-term borrowing, possible state takeover of finances, and the lack of a debt limit law, discourage privatization. However, a balanced budget law discourages privatization as well.

The results on switching from inhouse provision to contracting hetween 1987 and 1992 generally have the same sign as the results on the 1987 cross-section, although the magnitude of the effects is smaller and the statistical significance lower. The one case where the switching is significantly affected by a political variable, whereas the 1987 level is not, is the fraction of voters in the county that supported a republican candidate for governor in the previous election. This variable represents a recent event in each county, and hence it is not surprising that it predicts switchers to privatization rather than the level of privatization. The results on switching from private to inhouse provision between 1987 and 1992 are also generally in the same direction as the cross-sectional results, hut weaker. Contrary to what we would predict, more money in the rainy day fund reduces the likelihood of nationalization. Many other effects, including electoral results, are insignificant.

There is a good reason why in general we have stronger results for the 1987 cross-section than for the switchers, especially using state law variables. Our evidence indicates that, by 1987 , the mode of provision of county services has heen more or less established; the system is in the steady state. Newly added services are provided disproportionately privately, but there is about as much shifting from 
inhouse to private provision as backwards. Without a trend toward privatization, we can estimate the determinants of the steady state modes of provision more precisely than the determinants of switching, which are the faster moving variables. For this reason, most of our discussion focuses on the 1987 crosssection.

Table 4 presents the slope estimates from a probit and an OLS regression that includes all the relevant variables, and controls for state and county characteristics as well as service effects. We pool all of our county-service observations, a total of 6,997 for 2,453 counties. The OLS and probit results are extremely similar, so we discuss the OLS results, and mention probits when there are material differences.

Table 4 confirms the significance of state clean government laws in promoting privatization. States that require their counties to use a merit system have a 2.6 percentage point higher probability of privatizing their services. States that set purchasing standards have a 10 percentage point higher likelihood of contracting out. States that forbid government employees to engage in political activity have a 6.5 percentage points higher probability of privatization. And states that allow strikes by government employees have an 11 percentage point lower probability of privatization. All these effects are statistically significant, except for the merit system law which is marginally significant in the OLS regression and insignificant in the probit. This evidence supports the theory that political benefits of public control are an important obstacle to privatization.

The fraction of county votes for a republican gubernatorial candidate is statistically significant, but the effect is small. As that fraction rises by 10 percentage points (a large swing), the probability that a service in that county is privatized rises by 1 percentage point. The relatively small size of the effect may mean that elections primarily affect switchers. Alternatively, ideology may he a less important determinant of privatization than political patronage.

Table 4 also confirms our preliminary results on the labor market variables. The 1986 
unemployment rate has a statistically significant, but small, effect on privatization. A one percentage point rise in the unemployment rate in a county reduces the probability of privatization of a service in that county by .06 percentage points. The wage premium comes out with a statistically significant and positive (though small) coefficient. A 10 percentage point increase in the wage premium (say from 1.1 to 1.2 ) raises the likelihood of privatization by .3 of a percentage point. Finally, the fraction of county employees represented by bargaining units comes out highly significant and negative, indicating that strong unions deter privatization. As this fraction rises by .1, the probability of privatization falls by 1 percentage point. Together with the effect of the strikes variable above, the negative union effect on privatization is a clear finding of our empirical work.

Lastly, we turn to the budget constraint variables. The effect of the state law authorizing counties to issue short term debt is to lower the probability of privatization by 4.5 percentage points. The effect of the state law imposing debt limits on counties is to raise that probability by 6.3 percentage points. The effect of the balanced budget mandate is still statistically significant and "of the wrong sign", implying that counties facing this restriction have a 6 percentage points lower probability of privatization. The possibility of state takeover of county finances reduces the probability of privatization by a somewhat implausible 10 percentage points. The state's power to assess county property taxes -- our sole tax variable -- is insignificant. And finally, the estimated coefficient on the rainy day fund variable is statistically significant and negative. This is consistent with the prediction that softer budget constraints, which are perhaps associated with larger fund balances -- reduce the likelihood of privatization. By and large, the evidence here suggests that harder budget constraints on counties are associated with a higher likelihood of contracting out public services, consistent with both the efficiency and the political patronage theories.

\section{Statistical Issues}


One potential statistical problem with our evidence is a sample selection bias resulting from nonprovision of many services by many counties. After all, around 20 percent of the counties in our sample did not provide any of the twelve services at all, and more generally close to 80 percent of the possible county-services that can be provided are not. Non-provision can result either because the population in a given area does not get the service from any level of government, or because it gets the service from another level of government, such as the township, the municipality or the state. We cannot easily ascertain from our data what the situation is; nor do we have a good theoretical prediction of what the selection bias is. Nonetheless, we used several strategies to deal with it.

The simplest, and perhaps the most plausible, strategy is to include in the Table 4 regressions a measure of intensity of service provision in each state. We defined this measure as the ratio of all county-services actually provided in a given state to the total possible number of county-services that can be provided by that state (i.e., 12 times the number of counties in the state). This variable was not significant in the regressions, and did not materially affect any key coefficients.

A second strategy is to select a subsample of counties in which non-provision is relatively uncommon, and to run the basic regression on this subsample. The best exogenous predictors of provision we have are bank assets per resident in a county and the level of educational attainment. The results for this subsample, presented in the last column of Table 4, are in general close in magnitude and statistical significance to the basic results. Again, we do not conclude from this evidence that sample selection substantially biases our results . $^{8}$

A second methodological concern deals with our standard errors as well as the interpretation of the evidence. Specifically, in this analysis, we could not control for individual county fixed effects, since

\footnotetext{
${ }^{8}$ We have also estimated an ordered probit, in which non-provision is viewed as a third option, more extreme than contracting out. The estimated coefficients were generally of the same sign as those in Table 4, but further away from zero (and still statistically significant). These results confirm that non-provision may be a more extreme option than contracting out, but do not indicate that selection bias can account for the results in Table 4 .
} 
this would have eliminated much of our variation. If there is a county-specific taste for privatization, driven for example by a county-specific anti-government sentiment, then our estimated standard errors are too low. Moreover, if this taste is correlated with the presence of clean government laws, our interpretation of the evidence as supporting the political model may be inaccurate. The same reasoning applies at the state level as well, where all the observations in a state may be reflecting a common statespecific political sentiment. We focus on distinguishing the political patronage and ideology views later. We start with some alternative specifications that try to take account of the possible correlation of error terms across observations.

First, instead of using multiple service observations for each county, we look at individual services and run the regressions across counties. Table 5 presents the results of probits for the five most commonly county-provided services in our sample: airports ( 820 observations), landfills (1544 observations), hospitals (710 observations), nursing homes (629 observations), and libraries (1272) observations. For individual services, the coefficients are generally of the same sign as for the pooled sample, although the statistical significance of some of the results is lower. The results that remain most pronounced after disaggregation are on the clean government laws (state merit system, state purchasing standards, and state prohibition of political activities all encourage privatization, whereas laws allowing strikes discourage it). The voting variable continues to be positive, though not significant for any individual service. The labor market results are statistically weaker. Hard budget constraints results are also weaker statistically, though the signs of coefficients are generally the same as in the pooled regression. The possibility of issuing short term debt generally has a negative effect, whereas debt limits generally have a positive effect. The balanced budget coefficients flip around. The effect of the possibility of state takeover of finances on privatization is negative in three out of five cases, and statistically significant in all of those, and not in the other two. The effect of the state having power to assess county taxes is in general positive. Finally, the effect of higher balances in the rainy day fund is 
very consistently negative and significant, supporting the results of the pooled regression.

In addition to service-specific regressions, we aggregate observations across services in each county first, and across counties in a given state second. We focus on the top six most commonly provided services. The measure of privatization for each county is the ratio of the number of the top six services contracted out by that county to the number of the top six services it provides. The measure of privatization we use for each state is the county-population-weighted average of the privatization measures for the counties in that state. The results are presented in Table 6.

County-level results are generally similar in magnitude but weaker in significance than the results in Table 4. The effects of clean government laws are of comparable magnitude and statistical significance. The coefficient on republican votes is of similar magnitude but not statistically significant. Labor variables lose significance, although unionization remains a statistically and substantively significant deterrent to privatization. Some though not all of the hard budget constraint variables lose significance, although the coefficients are quite similar to those in Table 4.

The state level results (for which we have only 48 observations but quite a few explanatory variables) are weaker. The effect of a merit system is no longer significant. The purchasing standards coefficient switches sign. But the prohibition against political activity by government employees continues to encourage privatization, as does the prohibition against public employee strikes. The unemployment rate loses significance, but the public wage premium is strongly positively associated with privatization, consistent with the patronage theory. Public unionization deters privatization as before, although the effect is no longer significant. The results on hard budget constraint variables are more mixed, since the statistical significance of many coefficients disappears. In sum, the state-level results are statistically weaker than either our initial results or even the county level results, although the signs and magnitudes of many coefficients are comparable. 


\section{Interpretation}

Most of the evidence we have presented suggests that clean government laws are associated with more, tough unions with less, and hard hudget constraints with more privatization of local government services. This evidence is quite clear in our basic regressions using county-services as units of observation, and it survives the corrections for sample selection and the aggregation of services to the county level. The results are statistically weaker if we aggregate and use only 48 state level observations. What does this evidence imply for the three theories of privatization that we outlined in section II?

The evidence on the importance of clean government laws suggests that efficiency is not the only determinant of the decision to privatize. If efficiency were the sole determinant of privatization, then clean government laws would have no effect. Importantly, the evidence does not imply that efficiency does not matter, but only that it is not the whole story.

The evidence is also broadly consistent with the political patronage theory of privatization. State clean government laws that lower the henefits of political control are actually associated with a higher probability of privatization, and the labor market variables, such as public unionization and the unemployment rate, generally point in favor of this theory as well.

Finally, the evidence is in principle compatible with the ideology theory, according to which voters in some regions have a strong anti-government sentiment, which causes them to pass antigovernment laws (such as hard budget constraint laws and clean government laws) as well as to privatize. According to this theory, all we are capturing is unobserved heterogeneity among regions of the country. While we have tried to control for the political sentiment of the population by looking at the republican votes in each county, as well as for a variety of other variables that might be correlated with local antigovernment sentiment, such as education, income and wealth, distinguishing between the two interpretations of the evidence is difficult.

One further piece of evidence that we found informative is presented in Table 7 . This table 
shows the correlations across states between the existence of the various laws in these states, as well as of republican votes. Two points about this table are noteworthy. First, many of the clean government laws -- including merit system and prohibition of employee participation in politics -- are negatively correlated with republican votes. Similarly, some hard budget constraint laws -- including state debt limits on counties and state power to assess county property taxes -- are negatively correlated with republican votes. To us, this evidence is inconsistent with the view that all the laws are driven by voter anti-government sentiment, which is probably at least somewhat related to republican votes. Second, the correlations between different clean government and budgetary limit laws are typically small and often "of the wrong sign". This evidence too makes us skeptical about the ideology theory.

\section{Switchers}

As we showed earlier, there is no significant trend toward either privatization or nationalization between 1987 and 1992. However, we do have some "fast moving" variables that may be as important for determining the transitions in the provision mode as they are for the long run equilibrium. For example, our rainy day fund variable, which captures the 1987 available emergency resources of the state government, should theoretically determine the transition in provision modes between 1987 and 1992 . Similarly, the percentage of votes for the republican gubernatorial candidate is likely to reflect recent ideological shifts and not just long-run political sentiment of the electorate. As such, this variable should be a predictor of changes in the provision mode and not just the distribution in 1987.

Table 8 deals with the switchers. First, we look at the subsample of county services that were provided inhouse in 1987 , and examine which ones of these switched to provision by private contract in 1992 and which ones stayed inhouse. We control for 1987 county government employment per 1000 inhabitants, on the theory that a higher concentration of public employees might deter privatization. Consistent with the view that the system has achieved an equilibrium by 1987 , the results are considerably 
weaker than for the cross-section. The competitive bidding variable remains an important predictor of switching to private supply, although it is possible that states where privatization is favored also try to make sure that contracting is clean, and hence introduce purchasing standards. The republican votes variable also has the predicted effect. Allowing public employees to strike remains a key factor in preventing the switch to privatization. Two soft budget constraint variables are statistically significant. State laws which authorize counties to issue short-term debt make contracting out less likely. High balances in state rainy day funds make contracting less likely.

Although these results are weaker than the cross-sectional results, the two fast moving variables that are likely to be the short run stimuli to privatization, namely republican votes and rainy day balances, both enter significantly. Moreover, the signs of other coefficients are generally consistent with the crosssectional evidence.

The only statistically significant variables in the nationalization regression are state purchasing standards, county unemployment rate, union representation, concentration of public employees, and state power to assess county taxes. With the exception of the last variable, all have the signs predicted by the political theory. This regression suggests that union and labor market pressures are most important for counties bringing contracted out services inhouse. The other effects are not statistically significant, but usually have the right sign for the political theory. These results, therefore, continue to provide some evidence favoring the importance of the political determinants of the contracting decision.

\section{Conclusion}

The results of our paper are inconsistent with the theory that efficiency considerations alone determine the decision to privatize. Although our empirical evidence does not imply that the efficiency considerations are unimportant, it suggests that they are not the whole story. The results are also difficult, though possible, to reconcile with the view that anti-government sentiment alone drives the 
privatization decision.

Our evidence suggests instead that among the important determinants of the privatization decision are its political benefits and costs. Politicians derive significant benefits from inhouse provision of public services -- such as political patronage, support from public employee unions, control of unemployment through public payrolls -- and may lose these benefits as a result of privatization. Consistent with this theory, we find that factors that reduce the political benefits from inhouse provision, especially state clean government and anti-union laws, make privatization more likely. Politicians give up the patronage benefits when they are not too large.

The other side of the coin of course is that voters do not like taxes, and the only way the politicians can pay for the patronage is through higher government spending. Taxpayer opposition to such spending is the political cost of inhouse provision, and the political benefit of privatization. Consistent with this theory, we find that factors that increase the cost of government spending, such as state laws restricting government financing and measures of state's financial trouble, make privatization more likely. Politicians give up the patronage benefits when they become too expensive.

These results support the political tradeoff theory articulated in Boycko, Shleifer and Vishny (1994) and Shleifer and Vishny (1994). The privatization decision is determined to a significant extent by the tradeoff that politicians face between inhouse provision of public services, which brings them political benefits, and higher government spending, which brings them political costs. This political tradeoff, and not just the efficiency and ideological factors, is likely to determine the decision to privatize government services. 
References.

American Federation of State, County and Municipal Employees (1984), Passing the Bucks: The Contracting out of Public Services. Washington, DC: AFSCME.

Boycko, Maxim, Andrei Shleifer and Robert W. Vishny (1994), "A Theory of Privatization," forthcoming as Paish Lecture, Economic Journal.

Donahue, John D . (1989), The Privatization Decision: Public Ends. Private Means, New York, NY: Basic Books.

Grossman, Sanford J. and Oliver D. Hart (1986), "The Costs and Benefits of Ownership: a Theory of Vertical and Lateral Integration," Journal of Political Economy 94: 691-719.

Hart, Oliver D., Andrei Shleifer, and Robert W. Vishny (1995?), "What Should Governments Do?", Mimeo in preparation.

International City Management Association (1989), Service Delivery in the 1990s: Alternative Approaches for Local Governments, Washington, DC: ICMA.

Kemp, Roger L., ed. (1991), Privatization: The Provision of Public Services by the Private Sector, Jefferson, N.C.: McFarland and Co.

Kodrzycki, Yolanda K. (1994), "Privatization of Local Public Services: Lessons for New England," New 
England Economic Review, May-June: 31-46.

Kwoka, John E., Jr. (1994), "Does Public vs. Private Ownership Matter? Price and Cost Performance in Electric Utilities," Mimeo.

Laffont, Jean-Jacques (1994), "Regulation, Privatization, and Incentives in Developing Countries," Mimeo.

López-de-Silanes, Florencio (1994), "Determinants of Privatization Prices, " Harvard University Mimeo.

Megginson, William L., Rohert C. Nash and Mathias van Randenborgh (1994), "The Financial and Operating Performance of Newly Privatized Firms: an International Empirical Analysis," Journal of Finance XLIX: 403-52.

National Commission for Employment Policy (1988), Privatization and Public Employees: The Impact of City and County Contracting on Government Workers. Washington, DC: NCEP.

Poterba, James M. (1994), "States Responses to Fiscal Crises: the Effects of Budgetary Institutions and Politics, " Journal of Political Economy 102: 799-821.

Poterba, James M. and Kim S. Rueben (1995), "Fiscal Institutions and Public Sector Labor Markets," Mimeo, MIT. 
Sappington, David E.M. and Joseph E. Stiglitz (1987), "Privatization, Information, and Incentives," Journal of Policy Analysis and Management 6: 567-582.

Savas, Emanuel S. (1982), Privatizing the Public Sector; How to Shrink Government, Chatham, N.J.: Chatham House Publishing.

Savas, Emanuel S. (1987), Privatization: The Key to Better Government, Chatham, N.J.: Chatham House Publishing.

Shapiro, Carl and Robert Willig (1990), "Economic Rationales for the Scope of Privatization," in Ezra N. Suleiman and John Waterbury, eds., The Political Economy of Public Sector Reform and Privatization, Boulder, Co.: Westview Press.

Shleifer, Andrei and Robert W. Vishny (1994), "Politicians and Firms," Quarterly Journal of Economics: 995-1025.

Stevens, Barbara J. (1984), Delivering Municipal Services Efficiently: A Comparison of Municipal and Private Service Delivery, Washington, DC.: Office of Policy Development and Research, Department of Housing and Urban Development.

Stigler, George J. (1971), "The Theory of Economic Regulation," Bell Journal of Economics 2: 3-21.

United States Advisory Commission on Intergovernmental Relations (1993), State Laws Governing Local Government Structure and Administration. Washington, DC: U.S.A.C.I.R. 
Table 1

\section{Service Provision by County Governments in the United States}

This table shows the 12 services recorded by the Census of Governments from the Bureau of the Census. The number of counties providing each scrvice is reported below. The numbers in parentheses represent the percentage over the total number of counties in the United States $(3,042$ counties $)$.

\begin{tabular}{|c|c|c|c|c|c|c|}
\hline \multirow[b]{2}{*}{ Service } & \multicolumn{3}{|c|}{ Counties with Service Provision in 1987} & \multicolumn{3}{|c|}{ Counties with Service Provision in 1992} \\
\hline & $\begin{array}{c}\text { Provided by the } \\
\text { County } \\
\text { Government } \\
\text { (\% of counties) }\end{array}$ & $\begin{array}{c}\text { Provided by a } \\
\text { Private } \\
\text { contractor } \\
\text { (\% of counties) }\end{array}$ & $\begin{array}{c}\text { Total } \\
\text { (\% of counties) }\end{array}$ & $\begin{array}{c}\text { Provided by the } \\
\text { County } \\
\text { Government } \\
\text { (\% of countics) }\end{array}$ & $\begin{array}{c}\text { Provided by a } \\
\text { Private } \\
\text { Contractor } \\
\text { (\% of counties) }\end{array}$ & $\begin{array}{c}\text { Total } \\
\text { (\% of countics) }\end{array}$ \\
\hline Hospitals & $\begin{array}{c}476 \\
(15.7 \%)\end{array}$ & $\begin{array}{c}245 \\
(8.1 \%)\end{array}$ & $\begin{array}{c}721 \\
(23.7 \%)\end{array}$ & $\begin{array}{c}391 \\
(12.9 \%)\end{array}$ & $\begin{array}{c}337 \\
(11.1 \%)\end{array}$ & $\begin{array}{c}728 \\
(23.9 \%)\end{array}$ \\
\hline Landfills & $\begin{array}{c}1,261 \\
(41.5 \%)\end{array}$ & $\begin{array}{c}323 \\
(10.6 \%)\end{array}$ & $\begin{array}{c}1,584 \\
(52.1 \%)\end{array}$ & $\begin{array}{c}1,208 \\
(39.7 \%)\end{array}$ & $\begin{array}{c}415 \\
(13.6 \%)\end{array}$ & $\begin{array}{c}1,623 \\
(53.4 \%)\end{array}$ \\
\hline Librarics & $\begin{array}{c}1,128 \\
(37.1 \%)\end{array}$ & $\begin{array}{c}177 \\
(5.8 \%)\end{array}$ & $\begin{array}{c}1,305 \\
(42.9 \%)\end{array}$ & $\begin{array}{c}1,133 \\
(37.3 \%)\end{array}$ & $\begin{array}{c}340 \\
(11.2 \%)\end{array}$ & $\begin{array}{c}1,473 \\
(48.4 \%)\end{array}$ \\
\hline Nursing Homes & $\begin{array}{c}489 \\
(16.1 \%)\end{array}$ & $\begin{array}{c}155 \\
(5.1 \%)\end{array}$ & $\begin{array}{c}644 \\
(21.2 \%)\end{array}$ & $\begin{array}{c}437 \\
(14.4 \%)\end{array}$ & $\begin{array}{c}214 \\
(7.0 \%)\end{array}$ & $\begin{array}{c}751 \\
(21.4 \%)\end{array}$ \\
\hline Public Transit & $\begin{array}{c}148 \\
(4.9 \%)\end{array}$ & $\begin{array}{c}87 \\
(2.9 \%)\end{array}$ & $\begin{array}{c}235 \\
(7.7 \%)\end{array}$ & $\begin{array}{c}187 \\
(6.2 \%)\end{array}$ & $\begin{array}{c}176 \\
(5.8 \%)\end{array}$ & $\begin{array}{c}363 \\
(11.9 \%)\end{array}$ \\
\hline Sewcrage & $\begin{array}{c}310 \\
(10.2 \%)\end{array}$ & $\begin{array}{c}69 \\
(2.3 \%)\end{array}$ & $\begin{array}{c}379 \\
(12.5 \%)\end{array}$ & $\begin{array}{c}321 \\
(10.6 \%)\end{array}$ & $\begin{array}{c}139 \\
(4.6 \%)\end{array}$ & $\begin{array}{c}460 \\
(15.1 \%)\end{array}$ \\
\hline Sladiums & $\begin{array}{c}140 \\
(4.6 \%)\end{array}$ & $\begin{array}{c}38 \\
(1.3 \%)\end{array}$ & $\begin{array}{c}178 \\
(5.9 \%)\end{array}$ & $\begin{array}{c}151 \\
(5.0 \%)\end{array}$ & $\begin{array}{c}62 \\
(2.0 \%)\end{array}$ & $\begin{array}{c}213 \\
(7.0 \%)\end{array}$ \\
\hline Fire Protection & $\begin{array}{c}607 \\
(20.0 \%)\end{array}$ & $\begin{array}{c}173 \\
(5.7 \%)\end{array}$ & $\begin{array}{c}780 \\
(25.6 \%)\end{array}$ & $\begin{array}{c}640 \\
(21.0 \%)\end{array}$ & $\begin{array}{c}368 \\
(12.1 \%)\end{array}$ & $\begin{array}{c}1,008 \\
(33.1 \%)\end{array}$ \\
\hline Airports & $\begin{array}{c}585 \\
(19.2 \%)\end{array}$ & $\begin{array}{c}250 \\
(8.2 \%)\end{array}$ & $\begin{array}{c}835 \\
(27.5 \%)\end{array}$ & $\begin{array}{c}574 \\
(18.9 \%)\end{array}$ & $\begin{array}{c}328 \\
(10.8 \%)\end{array}$ & $\begin{array}{c}902 \\
(29.7 \%)\end{array}$ \\
\hline Water Supply & $\begin{array}{c}312 \\
(10.3 \%)\end{array}$ & $\begin{array}{c}81 \\
(2.7 \%)\end{array}$ & $\begin{array}{c}393 \\
(12.9 \%)\end{array}$ & $\begin{array}{c}336 \\
(11.1 \%)\end{array}$ & $\begin{array}{c}178 \\
(5.9 \%)\end{array}$ & $\begin{array}{c}514 \\
(16.9 \%)\end{array}$ \\
\hline Elcctric Utility & $\begin{array}{c}18 \\
(0.6 \%)\end{array}$ & $\begin{array}{c}50 \\
(1.6 \%)\end{array}$ & $\begin{array}{c}68 \\
(2.2 \%)\end{array}$ & $\begin{array}{c}6 \\
(0.2 \%)\end{array}$ & $\begin{array}{c}149 \\
(4.9 \%)\end{array}$ & $\begin{array}{c}155 \\
(5.1 \%)\end{array}$ \\
\hline Gas Utility & $\begin{array}{c}14 \\
(0.5 \%)\end{array}$ & $\begin{array}{c}49 \\
(1.6 \%)\end{array}$ & $\begin{array}{c}63 \\
(2.1 \%)\end{array}$ & $\begin{array}{c}17 \\
(0.6 \%)\end{array}$ & $\begin{array}{c}136 \\
(4.5 \%)\end{array}$ & $\begin{array}{c}153 \\
(5.0 \%)\end{array}$ \\
\hline $\begin{array}{l}\text { Total Number of } \\
\text { services provided } \\
\text { (\% of services) }\end{array}$ & $\begin{array}{c}5,488 \\
(15.0 \%)\end{array}$ & $\begin{array}{c}1,697 \\
(4.7 \%)\end{array}$ & $\begin{array}{c}7,185 \\
(19.7 \%)\end{array}$ & $\begin{array}{c}5,401 \\
(14.8 \%)\end{array}$ & $\begin{array}{c}2,842 \\
(7.8 \%)\end{array}$ & $\begin{array}{c}8,243 \\
(22.6 \%)\end{array}$ \\
\hline
\end{tabular}


Table 2

Provision across Time

\begin{tabular}{c||ccc|c}
\hline \multicolumn{1}{c||}{} & \multicolumn{4}{c}{ Service Provision in 1992 by: } \\
\cline { 2 - 5 } $\begin{array}{c}\text { Service Provision in } 1987 \\
\text { by: }\end{array}$ & $\begin{array}{c}\text { County } \\
\text { Government }\end{array}$ & $\begin{array}{c}\text { Private } \\
\text { Contractor }\end{array}$ & $\begin{array}{c}\text { None of the } \\
\text { above }\end{array}$ & Total: \\
\hline \hline County Government & 3,888 & 533 & 1,067 & 5,488 \\
& $(10.7 \%)$ & $(1.5 \%)$ & $(2.9 \%)$ & $(15.0 \%)$ \\
Private Contractor & 363 & 647 & 687 & 1,697 \\
& $(1.0 \%)$ & $(1.8 \%)$ & $(1.9 \%)$ & $(4.7 \%)$ \\
None of the above & 1,150 & 1,662 & 26,507 & 29,319 \\
& $(3.2 \%)$ & $(4.6 \%)$ & $(72.6 \%)$ & $(80.3 \%)$ \\
& & & & \\
& & & & \\
& 5,401 & 2,842 & 28,261 & 36,504 \\
& $(14.8 \%)$ & $(7.8 \%)$ & $(77.4 \%)$ & $(100 \%)$ \\
\hline
\end{tabular}


TABLE 3

Probability of Service Provision

The population is the total number of U.S. counties $(3,042)$. The first dependent variable, "Service provided by Private Contractor in 1987", is a dummy variable equal to 1 if the service was provided by a private firm in 1987, and 0 if the service was provided by the local county government. The second dependent variable, "Switched to Private Contractor provision in 1992", is a dummy variable equal to 1 if the service was provided by the local government in 1987 and switched to be provided by a private firm by 1992, and 0 if the service continued to be provided by the county government in 1992. This variable is equivalent to a privatization dummy. The third dependent variable is equivalent to a nationalization dummy which equals 1 if the service was provided by a private firm in 1987 and switched to be provided by the county government by 1992, and 0 if it continued to be provided by a private firm in 1992. The first column in each of the three panels shows the means of the independent variables for the different values of the dependent variable. The second column in each panel shows the difference in means and the t-statistic of a difference in means test assuming unequal variance.

\begin{tabular}{|c|c|c|c|c|c|c|c|}
\hline \multirow[b]{3}{*}{ Variable: } & & \multicolumn{6}{|c|}{ Mean Values of the Dependent Variables } \\
\hline & & \multicolumn{2}{|c|}{$\begin{array}{l}\text { Service provided by } \\
\text { Private Contractor in } \\
1987\end{array}$} & \multicolumn{2}{|c|}{$\begin{array}{l}\text { Switched to Private } \\
\text { Contractor provision in } \\
1992 \text { (Privatization) }\end{array}$} & \multicolumn{2}{|c|}{$\begin{array}{l}\text { Switched to County } \\
\text { Government provision in } \\
1992 \text { (Nationalization) }\end{array}$} \\
\hline & & Means & $\begin{array}{l}\text { Diff.in Means } \\
\quad(t-\text { stat })\end{array}$ & Means & $\underset{(t-s t a t)}{\text { Diff.in Means }}$ & Means & $\begin{array}{l}\text { Diff.in Means } \\
(t-s t a t)\end{array}$ \\
\hline Unrestricted Mean & & 0.2362 & & 0.1206 & & 0.3594 & \\
\hline \multicolumn{2}{|l|}{ A. Political Variables } & & & & & & \\
\hline $\begin{array}{l}\text { State law requires merit system } \\
\text { to the county }\end{array}$ & $\begin{array}{l}\text { Yes } \\
\text { No }\end{array}$ & $\begin{array}{l}0.2655 \\
0.2224\end{array}$ & $\begin{array}{l}0.0431^{*} \\
(3.93)\end{array}$ & $\begin{array}{l}0.1240 \\
0.1191\end{array}$ & $\begin{array}{l}0.0049 \\
(0.44)\end{array}$ & $\begin{array}{l}0.2820 \\
0.4067\end{array}$ & $\begin{array}{l}-0.1248 \\
(-4.12)\end{array}$ \\
\hline $\begin{array}{l}\text { Statc law sets local purchasing } \\
\text { standards }\end{array}$ & $\begin{array}{l}\text { Yes } \\
\text { No }\end{array}$ & $\begin{array}{l}0.2507 \\
0.2081\end{array}$ & $\begin{array}{l}0.0426^{\circ} \\
(4.12)\end{array}$ & $\begin{array}{l}0.1254 \\
0.1123\end{array}$ & $\begin{array}{l}0.0131 \\
(1.31)\end{array}$ & $\begin{array}{l}0.3413 \\
0.4020\end{array}$ & $\begin{array}{l}-0.0607^{c} \\
(-1.81)\end{array}$ \\
\hline $\begin{array}{l}\text { State forbids political activity } \\
\text { for government employees }\end{array}$ & $\begin{array}{l}\text { Yes } \\
\text { No }\end{array}$ & $\begin{array}{l}0.2451 \\
0.2507\end{array}$ & $\begin{array}{l}0.0177^{\circ} \\
(1.77)\end{array}$ & $\begin{array}{l}0.1145 \\
0.1263\end{array}$ & $\begin{array}{r}-0.0118 \\
(-1.21)\end{array}$ & $\begin{array}{l}0.3445 \\
0.3763\end{array}$ & $\begin{array}{r}-0.0318 \\
(-1.05)\end{array}$ \\
\hline $\begin{array}{l}\text { State allows county employees } \\
\text { to strike }\end{array}$ & $\begin{array}{l}\text { Yes } \\
\text { No }\end{array}$ & $\begin{array}{l}0.2039 \\
0.2387\end{array}$ & $\begin{array}{c}-0.0348^{c} \\
(-1.87)\end{array}$ & $\begin{array}{l}0.0848 \\
0.1236\end{array}$ & $\begin{array}{c}-0.0388 \\
(-2.43)\end{array}$ & $\begin{array}{l}0.2985 \\
0.3637\end{array}$ & $\begin{array}{r}-0.0649 \\
(-1.12)\end{array}$ \\
\hline $\begin{array}{l}\text { Fraction of county votes for } \\
\text { repulblican governor }\end{array}$ & $\begin{array}{l}\geq 0.468 \\
<0.468\end{array}$ & $\begin{array}{l}0.2403 \\
0.2322\end{array}$ & $\begin{array}{l}0.0081 \\
(0.81)\end{array}$ & $\begin{array}{l}0.1350 \\
0.1064 \\
.1 .1\end{array}$ & $\begin{array}{l}0.0286^{n} \\
(2.92)\end{array}$ & $\begin{array}{l}0.3558 \\
0.3634 \\
\ldots\end{array}$ & 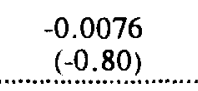 \\
\hline \multicolumn{2}{|l|}{ B. Labor Market Conditions } & & & & & & \\
\hline Unemployment rate in 1986 & $\begin{array}{l}\geq 0.087 \\
<0.087\end{array}$ & $\begin{array}{l}0.2456 \\
0.2290\end{array}$ & $\begin{array}{l}0.0166^{c} \\
(1.63)\end{array}$ & $\begin{array}{l}0.1295 \\
0.1141\end{array}$ & $\begin{array}{l}0.0154 \\
(1.54)\end{array}$ & $\begin{array}{l}0.3827 \\
0.3405\end{array}$ & $\begin{array}{l}0.0422 \\
(1.39)\end{array}$ \\
\hline $\begin{array}{l}\text { Wage premium } \\
\text { (Comty/Private) }\end{array}$ & $\begin{array}{l}\geq 1.154 \\
<1.154\end{array}$ & $\begin{array}{l}0.2404 \\
0.2336\end{array}$ & $\begin{array}{l}0.0068 \\
(0.68)\end{array}$ & $\begin{array}{l}0.1176 \\
0.1224\end{array}$ & $\begin{array}{r}-0.0048 \\
(-0.49)\end{array}$ & $\begin{array}{l}0.3533 \\
0.3660\end{array}$ & $\begin{array}{r}-0.0127 \\
(-0.42)\end{array}$ \\
\hline $\begin{array}{l}\text { Fraction of county government } \\
\text { workers in unions }\end{array}$ & $\begin{array}{l}\geq 0.095 \\
<0.095\end{array}$ & $\begin{array}{l}0.2001 \\
0.2486\end{array}$ & $\begin{array}{c}-0.0485 \\
(-4.34)\end{array}$ & $\begin{array}{l}0.1065 \\
0.1254\end{array}$ & $\begin{array}{l}-0.0189^{c} \\
(-1.76)\end{array}$ & $\begin{array}{l}0.4319 \\
0.3404\end{array}$ & $\begin{array}{l}0.0915^{\text {ต }} \\
(2.41)\end{array}$ \\
\hline $\begin{array}{l}\text { County government employees } \\
\text { per } 1000 \text { inllabitants }\end{array}$ & $\begin{array}{l}\geq 10.2 \\
<10.2\end{array}$ & 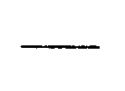 & 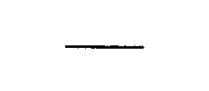 & $\begin{array}{l}0.1209 \\
0.1202\end{array}$ & $\begin{array}{l}0.0007 \\
(0.08)\end{array}$ & $\begin{array}{l}0.3954 \\
0.3322\end{array}$ & $\begin{array}{l}0.0633^{b} \\
(2.07)\end{array}$ \\
\hline \multicolumn{2}{|l|}{ C. Budget Constraints } & & & & & & \\
\hline $\begin{array}{l}\text { State allows counties to engage } \\
\text { in short-tcrm borrowing }\end{array}$ & $\begin{array}{l}\text { Yes } \\
\text { No }\end{array}$ & $\begin{array}{l}0.2189 \\
0.2770\end{array}$ & $\begin{array}{c}-0.0581^{a} \\
(-5.15)\end{array}$ & $\begin{array}{l}0.1054 \\
0.1623\end{array}$ & $\begin{array}{c}-0.0569 \\
(-4.73)\end{array}$ & $\begin{array}{l}0.3890 \\
0.3040\end{array}$ & $\begin{array}{l}0.0850^{n} \\
(2.74)\end{array}$ \\
\hline $\begin{array}{l}\text { State imposes debt limits on } \\
\text { counties }\end{array}$ & $\begin{array}{l}\text { Yes } \\
\text { No }\end{array}$ & $\begin{array}{l}0.2418 \\
0.2146\end{array}$ & $\begin{array}{l}0.0272 \\
(2.24)\end{array}$ & $\begin{array}{l}0.1237 \\
0.1088\end{array}$ & $\begin{array}{l}0.0148 \\
(1.28)\end{array}$ & $\begin{array}{l}0.3395 \\
0.4432\end{array}$ & $\begin{array}{c}-0.1039^{a} \\
(-2.63)\end{array}$ \\
\hline $\begin{array}{l}\text { State law mandates balanced } \\
\text { budget for counties }\end{array}$ & $\begin{array}{l}\text { Yes } \\
\text { No }\end{array}$ & $\begin{array}{l}0.2071 \\
0.2498\end{array}$ & $\begin{array}{c}-0.0427 \\
(-4.07)\end{array}$ & $\begin{array}{l}0.1101 \\
0.1262\end{array}$ & $\begin{array}{r}-0.0161 \\
(-1.59)\end{array}$ & $\begin{array}{l}0.3660 \\
0.3565\end{array}$ & $\begin{array}{l}0.0095 \\
(0.29)\end{array}$ \\
\hline $\begin{array}{l}\text { State "take over" of finances is } \\
\text { possible by state law }\end{array}$ & $\begin{array}{l}\text { Yes } \\
\text { No }\end{array}$ & $\begin{array}{l}0.1628 \\
0.2428\end{array}$ & $\begin{array}{c}-0.0800^{a} \\
(-5.00)\end{array}$ & $\begin{array}{l}0.0806 \\
0.1248\end{array}$ & $\begin{array}{c}-0.0442 \\
(-3.10)\end{array}$ & $\begin{array}{l}0.3944 \\
0.3568\end{array}$ & $\begin{array}{l}0.0376 \\
(0.62)\end{array}$ \\
\hline $\begin{array}{l}\text { State assesses county property } \\
\text { taxes }\end{array}$ & $\begin{array}{l}\text { Ycs } \\
\text { No }\end{array}$ & $\begin{array}{l}0.2212 \\
0.2380\end{array}$ & $\begin{array}{r}-0.0168 \\
(-1.06)\end{array}$ & $\begin{array}{l}0.1090 \\
0.1220\end{array}$ & $\begin{array}{r}-0.0130 \\
(-0.86)\end{array}$ & $\begin{array}{l}0.3246 \\
0.3638\end{array}$ & $\begin{array}{r}-0.0392 \\
(-0.84)\end{array}$ \\
\hline $\begin{array}{l}\text { State's "Rainy day Fund" as a } \\
\text { \% of State's total expenditures } \\
\text { in } 1987 .\end{array}$ & $\begin{array}{l}\geq 3.33 \\
<3.33\end{array}$ & $\begin{array}{l}0.2351 \\
0.2373\end{array}$ & $\begin{array}{r}-0.0022 \\
(-0.22)\end{array}$ & $\begin{array}{l}0.1153 \\
0.1263\end{array}$ & $\begin{array}{r}-0.0110 \\
(-1.12)\end{array}$ & $\begin{array}{l}0.3216 \\
0.3984\end{array}$ & $\begin{array}{c}-0.0768 \\
(-2.55)\end{array}$ \\
\hline
\end{tabular}


TABLE 4

\section{Cross-section of Service Provision in 1987}

Probit and Ordinary Least Squares regressions of the cross section of 3,042 counties in the United States. The Dependent Variable is constructed with data from the Census of Governments 1987, and refers to information about the extent of private contracting and local government provision for 12 different services. The dependent variable is a dummy variable equal to 1 when the local government engages in private contracting of the service, and 0 when the local government provides the service itself. For all other forms of provision or for the non provision of the service in the county the value of the dependent variable is set as missing. The third column shows the OLS regression results of a sample of the total population of counties which have a high probability of providing the service either inhouse or engaging in private contracting. The sample is selected based on the two main characteristics which increased the likelihood of provision. These two characteristics are the amount of bank deposits per capita in the county in 1987, and the percentage of the county population over 25 years old with a high school degree. This sample includes the 571 counties which fall in the intersection of the lowest 2 quintiles of both of the selection variables. The regressors are as defined as in previous tables. "County controls" include the following: total resident population of the county in 1987, and its square; the population density in the county (which is equal to the ratio of resident population over total square miles of county land area); the percentage of population over 25 years old which holds a high school degree; total bank deposits per capita in the county in 1987, and its square; per capita personal income in the county in 1987, and its square. "State Controls" correspond to the same variables as the county controls but at the State level. "Service dummies" reflect all the different 12 services, while "Region dummies" control for the nine different regions in the United States. For the Probit, derivatives are calculated based on the average of the scale factor in the casc of the continuous regressors, and as the average of the difference in the cumulative normal distributions evaluated with and without the dummy variable in the case of binomial regressors. For the OLS cases, the table reports coefficients and their White-corrected standard errors underneath in parenthesis.

\begin{tabular}{|c|c|c|c|}
\hline \multirow[b]{2}{*}{ Independent Variables } & \multicolumn{3}{|c|}{ Service Provision by Privatc Contractor in 1987} \\
\hline & Probit & Linear & $\begin{array}{c}\text { Linear } \\
\text { (high provision } \\
\text { sample) }\end{array}$ \\
\hline State law requires merit system for county & $\begin{array}{l}0.0229 \\
(0.0157)\end{array}$ & $\begin{array}{l}0.0261^{c} \\
(0.0152)\end{array}$ & $\begin{array}{c}0.0517 \\
(0.0370)\end{array}$ \\
\hline State law sets purchasing standards for the county & $\begin{array}{l}0.0956 \\
(0.0187)\end{array}$ & $\begin{array}{l}0.1031 \\
(0.0194)\end{array}$ & $\begin{array}{c}0.0645^{\circ} \\
(0.0304)\end{array}$ \\
\hline $\begin{array}{l}\text { State law forbids county employees to engage in } \\
\text { political activities }\end{array}$ & $\begin{array}{l}0.0577^{\circledR} \\
(0.0161)\end{array}$ & $\begin{array}{c}0.0651 \\
(0.0155)\end{array}$ & $\begin{array}{l}0.1395^{n} \\
(0.0337)\end{array}$ \\
\hline State law allows county employees to strike & $\begin{array}{l}-0.0934^{n} \\
(0.0251)\end{array}$ & $\begin{array}{l}-0.1097^{n} \\
(0.0289)\end{array}$ & $\begin{array}{l}-0.0909^{c} \\
(0.0414)\end{array}$ \\
\hline $\begin{array}{l}\text { Fraction of county gubernatorial votes for Republican } \\
\text { Governor }\end{array}$ & $\begin{array}{c}0.1027^{b} \\
(0.0480)\end{array}$ & $\begin{array}{c}0.1005^{b} \\
(0.0455)\end{array}$ & $\begin{array}{l}0.1985^{b} \\
(0.0857)\end{array}$ \\
\hline Unemployment rate in the county & $\begin{array}{l}-0.0574 \\
(0.0190)\end{array}$ & $\begin{array}{c}-0.0560^{n} \\
(0.0175)\end{array}$ & $\begin{array}{l}-0.0340 \\
(0.0275)\end{array}$ \\
\hline $\begin{array}{l}\text { Wage Premium of county employees over private sector } \\
\text { employees }\end{array}$ & $\begin{array}{c}0.0323^{b} \\
(0.0148)\end{array}$ & $\begin{array}{c}0.0337^{b} \\
(0.0143)\end{array}$ & $\begin{array}{l}0.0471^{\circ} \\
(0.0242)\end{array}$ \\
\hline $\begin{array}{l}\text { Fraction of County employees represented by } \\
\text { bargaining unions }\end{array}$ & $\begin{array}{l}-0.0865 \\
(0.0322)\end{array}$ & $\begin{array}{l}-0.0776^{n} \\
(0.0285)\end{array}$ & $\begin{array}{l}-0.0826^{c} \\
(0.0450)\end{array}$ \\
\hline State law authorizes counties to issue short-term debt & $\begin{array}{l}-0.0371^{c} \\
(0.0210)\end{array}$ & $\begin{array}{l}-0.0445^{b} \\
(0.0207)\end{array}$ & $\begin{array}{l}-0.0341 \\
(0.0374)\end{array}$ \\
\hline State law imposes debt limits on counties & $\begin{array}{l}0.0563 \\
(0.0247)\end{array}$ & $\begin{array}{c}0.0634^{b} \\
(0.0268)\end{array}$ & $\begin{array}{l}0.0260 \\
(0.0623)\end{array}$ \\
\hline State law mandates balanced budgets for counties & $\begin{array}{l}-0.0595^{a} \\
(0.0160)\end{array}$ & $\begin{array}{l}-0.05799^{\circ} \\
(0.0162)\end{array}$ & $\begin{array}{l}-0.1021^{n} \\
(0.0352)\end{array}$ \\
\hline $\begin{array}{l}\text { State law allows possibility of the State taking over the } \\
\text { financial administration of the county }\end{array}$ & $\begin{array}{l}-0.0972 \\
(0.0272)\end{array}$ & $\begin{array}{l}-0.0976 \\
(0.0280)\end{array}$ & $\begin{array}{l}-0.1632 \\
(0.0524)\end{array}$ \\
\hline $\begin{array}{l}\text { State law give the State the power to assess county } \\
\text { property taxes }\end{array}$ & $\begin{array}{l}0.0079 \\
(0.0250)\end{array}$ & $\begin{array}{l}-0.0115 \\
(0.0231)\end{array}$ & $\begin{array}{l}-0.1019^{b} \\
(0.0440)\end{array}$ \\
\hline $\begin{array}{l}\text { State's "Rainy Day Fund" as a percentage of State's } \\
\text { total expenditures in } 1987\end{array}$ & $\begin{array}{c}-0.0069 \\
(0.0013)\end{array}$ & $\begin{array}{c}-0.0072 a " \\
(0.0013)\end{array}$ & $\begin{array}{l}-0.0009 \\
(0.0033)\end{array}$ \\
\hline County belongs to a Regional Organization & $\begin{array}{c}0.0119 \\
(0.0120)\end{array}$ & $\begin{array}{c}0.0121 \\
(0.0118)\end{array}$ & $\begin{array}{l}-0.0017 \\
(0.0220)\end{array}$ \\
\hline Fraction of county population living in municipalities & $\begin{array}{c}0.1193^{\circ} \\
(0.0328)\end{array}$ & $\begin{array}{c}0.1113^{a} \\
(0.0280)\end{array}$ & $\begin{array}{c}0.16488^{\text {म }} \\
(0.0507)\end{array}$ \\
\hline County Controls & yes & yes & yes \\
\hline State Controls & yes & yes & yes \\
\hline Servicc dummies & yes & yes & yes \\
\hline Region dummies & yes & yes & yes \\
\hline Number of Observations & 6,997 & 6,997 & 2,478 \\
\hline Log Likclihood & -3521 & ----- & $\cdots$ \\
\hline Adjusted (or Pscudo) $\mathbf{R}^{2}$ & .0809 & .0836 & .1019 \\
\hline
\end{tabular}

aignificant at 1 percent. ${ }^{b}$ Significant at 5 percent. ${ }^{c}$ Significant at 10 percent. 
TABLE 5

Cross-section of Service Provision in 1987 for some Individual Services

Probil regressions of the cross scetion of 3,042 counties in the United States. The Dependent Variable is constructed with data from the Census of Governments 1987, and refers to information about the extent of private contracting and local government provision for each different scrvice. The dependent variable is a dummy variable equal to 1 when the local government engages in private contracting of the service, and 0 when the local government provides the service itsclf. For all other forms of provision or for the non provision of the service in the county the value of the dependent variable is set as missing. The regressors are as follows: "Wage premium" is the wage premium for government employees and is defines as the ratio of the average pay per county employec in 1987 over the average annual pay in industry in the county in 1987; "County controls" include the following: total resident population of the county in 1987, and its square; the population density in the county (which is equal to the ratio of resident population over total square miles of county land area); total bank deposits per capita in the county in 1987, and its square; per capita personal income in the county in 1987, and its square. "Statc Controls" correspond to the same variables as the county controls but at the State level. "Service dummies" reflect all the different 12 services, while "Region dummies" control for the nine different regions in the United States. The table reports derivatives and their standard errors underncath in parenthesis. The slopes or marginal effects are reported to the right. These are calculated based on the average of the scale factor in the case of the continuous regressors, and as the average of the difference in the cumulative normal distributions evaluated with and without the dummy variable in the case of binomial regressors.

\begin{tabular}{|c|c|c|c|c|c|}
\hline \multirow[b]{2}{*}{ Independent Variables } & \multicolumn{5}{|c|}{ Service Provision by Private Contractor in 1987} \\
\hline & Airports & Landfills & Libraries & $\begin{array}{l}\text { Nursing } \\
\text { Homes }\end{array}$ & Hospitals \\
\hline State law requires merit system for county & $\begin{array}{l}0.1125^{b} \\
(0.0519)\end{array}$ & $\begin{array}{c}0.0044 \\
(0.0316)\end{array}$ & $\begin{array}{c}0.0157 \\
(0.0276)\end{array}$ & $\begin{array}{c}0.0643 \\
(0.0520)\end{array}$ & $\begin{array}{l}-0.0615 \\
(0.0533)\end{array}$ \\
\hline State law scts purchasing standards for the county & $\begin{array}{c}0.1271^{b} \\
(0.0586)\end{array}$ & $\begin{array}{r}0.1876^{a} \\
(0.0336)\end{array}$ & $\begin{array}{c}0.0196 \\
(0.0325)\end{array}$ & $\begin{array}{c}0.0456 \\
(0.0616)\end{array}$ & $\begin{array}{l}-0.1549^{b} \\
(0.0737)\end{array}$ \\
\hline $\begin{array}{l}\text { State law forbids county employees to engage in } \\
\text { political activities }\end{array}$ & $\begin{array}{c}0.0323 \\
(0.0552)\end{array}$ & $\begin{array}{l}0.0970 \\
(0.0319)\end{array}$ & $\begin{array}{l}0.0468^{c} \\
(0.0272)\end{array}$ & $\begin{array}{c}0.0383 \\
(0.0532)\end{array}$ & $\begin{array}{c}0.0825 \\
(0.0603)\end{array}$ \\
\hline State law allows county employees to strike & $\begin{array}{l}-0.1625^{\circ} \\
(0.0688)\end{array}$ & $\begin{array}{l}-0.0199 \\
(0.0502)\end{array}$ & $\begin{array}{l}-0.0956^{a} \\
(0.0340)\end{array}$ & $\begin{array}{l}-0.0819 \\
(0.0753)\end{array}$ & $\begin{array}{c}0.0541 \\
(0.1037)\end{array}$ \\
\hline $\begin{array}{l}\text { Fraction of county gubernatorial votes for Republican } \\
\text { Governor }\end{array}$ & $\begin{array}{c}0.1260 \\
(0.1425)\end{array}$ & $\begin{array}{c}0.1255 \\
(0.0988)\end{array}$ & $\begin{array}{c}0.0714 \\
(0.0813)\end{array}$ & $\begin{array}{l}0.1839 \\
(0.1502)\end{array}$ & $\begin{array}{c}0.0362 \\
(0.1753)\end{array}$ \\
\hline Uncmployment rate in the county & $\begin{array}{l}-0.1035^{\circ} \\
(0.0564)\end{array}$ & $\begin{array}{l}-0.0105 \\
(0.0360)\end{array}$ & $\begin{array}{l}-0.0684^{b} \\
(0.0333)\end{array}$ & $\begin{array}{l}-0.0510 \\
(0.0631)\end{array}$ & $\begin{array}{l}-0.0793 \\
(0.0630)\end{array}$ \\
\hline $\begin{array}{l}\text { Wage Premium of county cmployecs over private sector } \\
\text { employees }\end{array}$ & $\begin{array}{l}-0.0170 \\
(0.0424)\end{array}$ & $\begin{array}{l}0.0408 \\
(0.0307)\end{array}$ & $\begin{array}{l}-0.0155 \\
(0.0266)\end{array}$ & $\begin{array}{c}0.1196^{b} \\
(0.0495)\end{array}$ & $\begin{array}{c}0.0187 \\
(0.0539)\end{array}$ \\
\hline $\begin{array}{l}\text { Fraction of County employees represented by } \\
\text { bargaining unions }\end{array}$ & $\begin{array}{l}-0.1188 \\
(0.0974)\end{array}$ & $\begin{array}{l}-0.14355^{b} \\
(0.0671)\end{array}$ & $\begin{array}{l}-0.0192 \\
(0.0553)\end{array}$ & $\begin{array}{l}-0.2364 \\
(0.0965)\end{array}$ & $\begin{array}{l}-0.1508 \\
(0.1370)\end{array}$ \\
\hline State law authorizes counties to issue slonrt-term debt & $\begin{array}{l}-0.0500 \\
(0.0656)\end{array}$ & $\begin{array}{c}0.0039 \\
(0.0399)\end{array}$ & $\begin{array}{l}-0.0328 \\
(0.0366)\end{array}$ & $\begin{array}{l}-0.0642 \\
(0.0699)\end{array}$ & $\begin{array}{l}-0.2247^{n} \\
(0.0750)\end{array}$ \\
\hline State law imposes debt limits on countics & $\begin{array}{l}0.0430 \\
(0.0937)\end{array}$ & $\begin{array}{c}0.1142^{a} \\
(0.0467)\end{array}$ & $\begin{array}{l}0.0660^{c} \\
(0.0338)\end{array}$ & $\begin{array}{l}0.0412 \\
(0.0752)\end{array}$ & $\begin{array}{l}-0.0907 \\
(0.0920)\end{array}$ \\
\hline Statc law mandates balanced budgets for counties & $\begin{array}{l}-0.0568 \\
(0.0516)\end{array}$ & $\begin{array}{l}-0.0484 \\
(0.0332)\end{array}$ & $\begin{array}{l}-0.0257 \\
(0.0298)\end{array}$ & $\begin{array}{l}0.0333 \\
(0.0553)\end{array}$ & $\begin{array}{c}0.2098^{\circ} \\
(0.0645)\end{array}$ \\
\hline $\begin{array}{l}\text { State law allows possibility of the State laking over the } \\
\text { financial administration of the county }\end{array}$ & $\begin{array}{l}-0.1160 \\
(0.0807)\end{array}$ & $\begin{array}{l}-0.1351^{*} \\
(0.0494)\end{array}$ & $\begin{array}{c}0.0052 \\
(0.0531)\end{array}$ & $\begin{array}{l}-0.1329^{c} \\
(0.0786)\end{array}$ & $\begin{array}{c}0.2881^{b} \\
(0.1382)\end{array}$ \\
\hline $\begin{array}{l}\text { Statc law give the State the power to assess county } \\
\text { property taxes }\end{array}$ & $\begin{array}{r}0.2371 \\
(0.0871)\end{array}$ & $\begin{array}{c}0.0305 \\
(0.0557)\end{array}$ & $\begin{array}{l}-0.0250 \\
(0.0363)\end{array}$ & $\begin{array}{l}0.1523 \\
(0.1176)\end{array}$ & $\begin{array}{l}0.0002 \\
(0.1010)\end{array}$ \\
\hline $\begin{array}{l}\text { State's "Rainy Day Fund" as a percentage of Statc's } \\
\text { total expenditures in } 1987\end{array}$ & $\begin{array}{l}-0.0060^{c} \\
(0.0032)\end{array}$ & $\begin{array}{c}-0.0068{ }^{a} \\
(0.0268)\end{array}$ & $\begin{array}{c}-0.0058 \\
(0.0019)\end{array}$ & $\begin{array}{l}-0.0035 \\
(0.0039)\end{array}$ & $\begin{array}{c}-0.0090^{b} \\
(0.0038)\end{array}$ \\
\hline County belongs to a Regional Organization & $\begin{array}{l}-0.0011 \\
(0.0351)\end{array}$ & $\begin{array}{c}0.0214 \\
(0.0234)\end{array}$ & $\begin{array}{c}0.0116 \\
(0.0204)\end{array}$ & $\begin{array}{c}0.0023 \\
(0.0339)\end{array}$ & $\begin{array}{l}-0.0520 \\
(0.0415)\end{array}$ \\
\hline Fraction of county population living in municipalitics & $\begin{array}{l}-0.0671 \\
(0.0976)\end{array}$ & $\begin{array}{c}0.0476 \\
(0.0674)\end{array}$ & $\begin{array}{r}0.1143 \\
10.0609 \\
1.06\end{array}$ & $\begin{array}{l}-0.0949 \\
(0.1063)\end{array}$ & $\begin{array}{c}0.1875 \\
(0.1243) \\
0.1\end{array}$ \\
\hline County Controls & yes & yes & yes & yes & yes \\
\hline State Controls & yes & yes & yes & yes & yes \\
\hline Service dummies & no & no & no & no & no \\
\hline Region dummies & yes & yes & yes & yes & yes \\
\hline Number of Observations & 820 & 1544 & 1272 & 629 & 710 \\
\hline Log Likclilood & -456 & -710 & -456 & -272 & -414 \\
\hline Pseudo $\mathbf{R}^{2}$ & .0903 & .0998 & .0835 & .2186 & .0907 \\
\hline
\end{tabular}

"Significant at 1 percent. ${ }^{5}$ Significant at 5 percent. ${ }^{c}$ Significant at 10 percent. 
TABLE 6

Cross-section of Service Provision in 1987; County and State levels

Ordinary Least Squares regressions for the cross section of 3,042 counties in the United States. The Dependent Variable is constructed with data from the Census of Governments 1987, and refers to information about the extent of private contracting and local government provision for 12 different services. The dependent variable at the county level considers the 6 most common services provided at the eounty level and is constructed as the number of services contracted out in county $i$ over the number of services provided by either the local government or a contractor. The dependent variable at the state level considers the 6 most common services provided at the county level and is equal to the weighted sum of the number of services contracted out in each county $i$ in state $j$ over the number of services provided in county $i$ in state $j$, the weights are caleulated as the population in county $i$ as a percentage of the total population in state $j$ in 1987. All regressors are as defined in previous tables. For the "State level" regression, the regressors are the mean value across counties in each state. "County controls" and "State Controls" are the same as in previous tables. "Region dummies" control for the nine different regions in the United States. The table reports coefficients and their White-corrected standard crrors underneath in parenthesis.

\begin{tabular}{|c|c|c|}
\hline \multirow[b]{2}{*}{ Independent Variables } & \multicolumn{2}{|c|}{ Service Provision by Private Contractor in 1987} \\
\hline & County Level & State I evel \\
\hline State law requires merit system for county & $\begin{array}{c}0.0385^{b} \\
(0.0197)\end{array}$ & $\begin{array}{c}0.0253 \\
(0.0195)\end{array}$ \\
\hline State law scts purchasing standards for the county & $\begin{array}{l}0.1065^{n} \\
(0.0246)\end{array}$ & $\begin{array}{l}-0.0166 \\
(0.0156)\end{array}$ \\
\hline $\begin{array}{l}\text { State law forbids county employees to engage in } \\
\text { political activities }\end{array}$ & $\begin{array}{l}0.0498^{b} \\
(0.0203)\end{array}$ & $\begin{array}{l}0.0495 \\
(0.0142)\end{array}$ \\
\hline State law allows county employees to strike & $\begin{array}{l}-0.1049^{a} \\
(0.0370)\end{array}$ & $\begin{array}{l}-0.0628^{c} \\
(0.0342)\end{array}$ \\
\hline $\begin{array}{l}\text { Fraction of county gubernatorial voles for Republican } \\
\text { Governor }\end{array}$ & $\begin{array}{c}0.0898 \\
(0.0606)\end{array}$ & $\begin{array}{l}0.1098 \\
(0.0836)\end{array}$ \\
\hline Uncmployment rate in the county & $\begin{array}{l}-0.0265 \\
(0.0235)\end{array}$ & $\begin{array}{c}0.0602 \\
(0.0428)\end{array}$ \\
\hline $\begin{array}{l}\text { Wage Premium of county cmployecs over private sector } \\
\text { cmployees }\end{array}$ & $\begin{array}{l}0.0065 \\
(0.0199)\end{array}$ & $\begin{array}{l}0.1970^{n} \\
(0.0453)\end{array}$ \\
\hline $\begin{array}{l}\text { Fraction of County employees represented by } \\
\text { bargaining unions }\end{array}$ & $\begin{array}{l}-0.1162^{a} \\
(0.0305)\end{array}$ & $\begin{array}{l}-0.1044 \\
(0.0694)\end{array}$ \\
\hline State law authorizes counties to issue short-term debt & $\begin{array}{l}-0.0166 \\
(0.0273)\end{array}$ & $\begin{array}{l}-0.0050 \\
(0.0252)\end{array}$ \\
\hline Statc law imposes debt limits on countics & $\begin{array}{l}0.0305 \\
(0.0334)\end{array}$ & $\begin{array}{l}0.0428^{b} \\
(0.0165)\end{array}$ \\
\hline State law mandates balanced budgets for counties & $\begin{array}{l}-0.0412^{c} \\
(0.0216)\end{array}$ & $\begin{array}{l}-0.0531 \\
(0.0163)\end{array}$ \\
\hline $\begin{array}{l}\text { State law allows possibility of the State taking over the } \\
\text { financial administration of the county }\end{array}$ & $\frac{-0.0957^{b}}{(0.0385)}$ & $\begin{array}{l}-0.0669^{b} \\
(0.0256)\end{array}$ \\
\hline $\begin{array}{l}\text { State law give the State the power to assess county } \\
\text { property taxes }\end{array}$ & $\begin{array}{r}0.0729^{h} \\
(0.0306)\end{array}$ & $\begin{array}{l}-0.0199 \\
(0.0246)\end{array}$ \\
\hline $\begin{array}{l}\text { State's "Rainy Day Fund" as a percentage of State's } \\
\text { total cxpenditures in } 1987\end{array}$ & $\begin{array}{l}-0.0040^{b} \\
(0.0019)\end{array}$ & $\begin{array}{l}-0.0013 \\
(0.0008)\end{array}$ \\
\hline County belongs to a Regional Organization & $\begin{array}{l}0.0225 \\
(0.0157)\end{array}$ & $\begin{array}{l}-0.0197 \\
(0.0604)\end{array}$ \\
\hline Fraction of county population living in municipalities & $\begin{array}{l}0.1260^{\circ} \\
(0.0387)\end{array}$ & $\begin{array}{l}0.0377 \\
(0.0826)\end{array}$ \\
\hline Constant & $\begin{array}{l}-1.3075^{h} \\
(0.5290)\end{array}$ & $\begin{array}{c}0.1821 \\
(0.4684)\end{array}$ \\
\hline County Controls & yes & no \\
\hline State Controls & yes & yes \\
\hline Service dummies & no & no \\
\hline Region dlummics & yes & yes \\
\hline Number of Obscrvations & 2,363 & 48 \\
\hline Adjusted $\mathbf{R}^{2}$ & .0589 & .4065 \\
\hline
\end{tabular}

n Significant at 1 percent. " Significant at 5 percent. " Significant at 10 percent. 
Table 7

Correlations of Variables at the State Level

Correlations of variables for the cross-section sample of county service provision in the United States in 1987 . Correlations are at the state level with 48 observations.

\begin{tabular}{|c|c|c|c|c|c|c|c|c|c|c|}
\hline Variable & $\begin{array}{l}\text { merit } \\
\text { system }\end{array}$ & $\begin{array}{l}\text { purchasing } \\
\text { standards }\end{array}$ & $\begin{array}{l}\text { no worker } \\
\text { politics }\end{array}$ & $\begin{array}{l}\text { strikes } \\
\text { allowed }\end{array}$ & $\begin{array}{l}\% \text { votes } \\
\text { republican }\end{array}$ & $\begin{array}{c}\text { no } \\
\text { short-term } \\
\text { debt }\end{array}$ & $\begin{array}{c}\text { debt } \\
\text { limits }\end{array}$ & $\begin{array}{c}\text { balanced } \\
\text { budget }\end{array}$ & $\begin{array}{l}\text { st. take } \\
\text { over }\end{array}$ & assess taxes \\
\hline $\begin{array}{l}\text { State law requires merit system for county } \\
\text { (merit system) }\end{array}$ & 1.00 & & & & & & & & & \\
\hline $\begin{array}{l}\text { State law sets purchasing standards for } \\
\text { counties (purch. stands.) }\end{array}$ & 0.039 & 1.00 & & & & & & & & \\
\hline $\begin{array}{l}\text { State law forbids county employees to } \\
\text { engage in political activity (no worker's } \\
\text { politics) }\end{array}$ & 0.155 & 0.090 & 1.00 & & & & & & & \\
\hline $\begin{array}{l}\text { State law allows county employees to strike } \\
\text { (strikes allowed) }\end{array}$ & 0.051 & 0.183 & 0.176 & 1.00 & & & & & & \\
\hline $\begin{array}{l}\text { Fraction of gubernatorial votes for } \\
\text { Republican candidate (votes republican) }\end{array}$ & -0.183 & 0.247 & -0.189 & -0.138 & 1.00 & & & & & \\
\hline $\begin{array}{l}\text { State law authorizes counties to have short- } \\
\text { term borrowing (short-t. debt) }\end{array}$ & -0.151 & -0.160 & -0.098 & 0.183 & -0.297 & 1.00 & & & & \\
\hline $\begin{array}{l}\text { State law imposes debt limits on counties } \\
\text { (debt limits) }\end{array}$ & 0.151 & -0.146 & -0.037 & 0.134 & -0.013 & -0.021 & 1.00 & & & \\
\hline $\begin{array}{l}\text { State constitution or statutory law mandates } \\
\text { a balanced budget for counties (balanced } \\
\text { budged) }\end{array}$ & 0.027 & -0.067 & 0.094 & 0.048 & -0.026 & -0.067 & 0.072 & 1.000 & & \\
\hline $\begin{array}{l}\text { State law allows that State may take over } \\
\text { the financial administration of county (st. } \\
\text { takeover) }\end{array}$ & 0.131 & 0.157 & 0.108 & -0.078 & -0.051 & 0.157 & -0.115 & 0.096 & 1.000 & \\
\hline $\begin{array}{l}\text { State law gives the State the power to assess } \\
\text { county property taxes (assess taxes) }\end{array}$ & 0.203 & -0.155 & 0.176 & -0.091 & -0.240 & 0.014 & 0.135 & 0.048 & 0.421 & 1.000 \\
\hline
\end{tabular}


TABLE 8

Privatization and Nationalization Switchers from 1987 to 1992

Probit regressions of the cross section of 3,042 countics in the United States. The Dependent Variable is constructed with data from the Census of Governments 1987 and 1992, and refers to information about the extent of private contracting and local government provision for 12 different $s$ The dependent variable for privatization is a dummy variable equal to 1 when, given that the county government provided the service in 1987 , if engaged in private contracting of the service by 1992 being a private contractor the supplier of the service, and 0 when the local goverament continues tofprovide the service itself. The dependent variable for nationalization is a dummy variable equal to 1 when, given that the county government engaged in private contracting to provide the service in 1987, it "nationalized" the service that is, stopped private contracting and supplies the service itself by 19 and 0 when the local government continues to contract out with a private contractor for the provision of the service. For all other changes of prov or for the non provision of the service in the county the value of both dependent variables is set as missing. The regressors are all defined as in $p$ tables. "County controls", "State Controls", Region dummies and Service dummies are all the same as in previous tables. The table reports coe and their standard errors underneath in parenthesis. The slopes or marginal effects are reported to the right. These are calculated based on the average of the scale factor in the case of the continuous regressors, and as the average of the difference in the cumulative normal distributions evaluated $w$ and without the dummy variable in the case of binomial regressors.

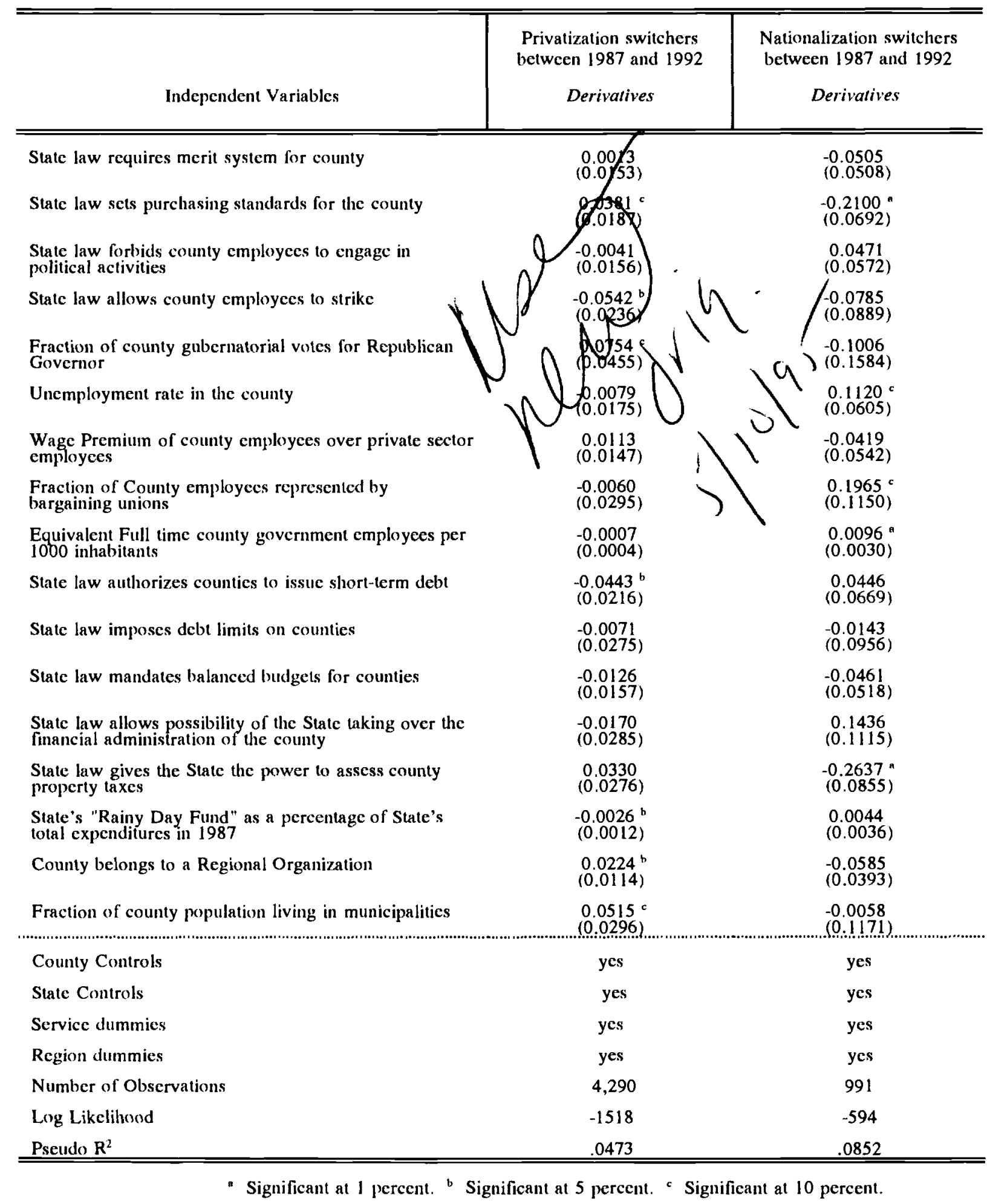




\section{TABLE 8}

\section{Privatization and Nationalization Switchers from 1987 to 1992}

Probit regressions of the cross section of 3,042 counties in the United States. The Dependent Variable is constructed with data from the Census of Governments 1987 and 1992 , and refers to information about the cxtent of private contracting and local government provision for 12 different services. The dependent variable for privatization is a dummy variable equal to 1 when, given that the county govermment provided the service in 1987 , it engaged in private contracting of the service by 1992 being a privalc contractor the supplier of the scrviec, and 0 when the local government eontinues to provide the service itself. The dependent variable for nationalization is a dummy variable cqual to 1 when, given that the county government engaged in private contracting to provide the service in 1987, it "nationalized" the service that is, stopped private contracting and supplies the service itself by 1992 , and 0 when the local government continues to contract out with a private contractor for the provision of the service. For all other changes of provision or for the non provision of the service in the county the value of both dependent variables is set as missing. The regressors are all defined as in previous tables. "County controls", "State Controls", Region dummies and Service dummies are all the same as in previous tables. The table reports cocfficients and their standard errors underneath in parenthesis. The slopes or marginal effects are reported to the right. These are calculated based on the average of' the scale factor in the case of the continuous regressors, and as the average of the difference in the eumulative normal distributions cvaluated with and withoul the dunmy variable in the case of binomial regressors.

\begin{tabular}{|c|c|c|}
\hline Independent Variables & $\begin{array}{c}\text { Privatization switchers } \\
\text { between } 1987 \text { and } 1992 \\
\text { Derivatives }\end{array}$ & $\begin{array}{c}\text { Nationalization switchers } \\
\text { between } 1987 \text { and } 1992 \\
\text { Derivarives }\end{array}$ \\
\hline Slate law requires meril system for comly & $\begin{array}{c}0.0013 \\
(0.0153)\end{array}$ & $\begin{array}{l}-0.0505 \\
(0.0508)\end{array}$ \\
\hline State law scts purchasing standards for the county & $\begin{array}{l}0.0381^{c} \\
(0.0187)\end{array}$ & $\begin{array}{l}-0.2100 \\
(0.0692)\end{array}$ \\
\hline $\begin{array}{l}\text { Stale law forbids county employees } 10 \text { engage in } \\
\text { political activities }\end{array}$ & $\begin{array}{l}-0.0041 \\
(0.0156)\end{array}$ & $\begin{array}{c}0.0471 \\
(0.0572)\end{array}$ \\
\hline Statc law allows counly employecs to strike & $\begin{array}{l}-0.0542 \\
(0.0236)\end{array}$ & $\begin{array}{l}-0.0785 \\
(0.0889)\end{array}$ \\
\hline $\begin{array}{l}\text { Fraction of county gubernatorial voles for Republican } \\
\text { Governor }\end{array}$ & $\begin{array}{c}0.0754^{\circ} \\
(0.0455)\end{array}$ & $\begin{array}{l}-0.1006 \\
(0.1584)\end{array}$ \\
\hline Unemployment rate in the county & $\begin{array}{l}-0.0079 \\
(0.0175)\end{array}$ & $\begin{array}{l}0.1120^{\circ} \\
(0.0605)\end{array}$ \\
\hline $\begin{array}{l}\text { Wage Premium of county employees over private sector } \\
\text { employees }\end{array}$ & $\begin{array}{l}0.0113 \\
(0.0147)\end{array}$ & $\begin{array}{l}-0.0419 \\
(0.0542)\end{array}$ \\
\hline $\begin{array}{l}\text { Fraclion of County employees represented by } \\
\text { bargaining unions }\end{array}$ & $\begin{array}{l}-0.0060 \\
(0.0295)\end{array}$ & $\begin{array}{l}0.1965^{c} \\
(0.1150)\end{array}$ \\
\hline $\begin{array}{l}\text { Equivalent Full time county government employees per } \\
1000 \text { inhabitants }\end{array}$ & $\begin{array}{l}-0.0007 \\
(0.0004)\end{array}$ & $\begin{aligned} 0.0096^{*} \\
(0.0030)\end{aligned}$ \\
\hline State law authorizes counties to issue short-term debt & $\begin{array}{l}-0.0443^{h} \\
(0.0216)\end{array}$ & $\begin{array}{c}0.0446 \\
(0.0669)\end{array}$ \\
\hline State law imposes debt linnits on countics & $\begin{array}{l}-0.0071 \\
(0.0275)\end{array}$ & $\begin{array}{l}-0.0143 \\
(0.0956)\end{array}$ \\
\hline State law mandates balanced budgets for countics & $\begin{array}{l}-0.0126 \\
(0.0157)\end{array}$ & $\begin{array}{l}-0.0461 \\
(0.0518)\end{array}$ \\
\hline $\begin{array}{l}\text { Slate law allows possibility of the Slate taking over the } \\
\text { financial administration of the combly }\end{array}$ & $\begin{array}{l}-0.0170 \\
(0.0285)\end{array}$ & $\begin{array}{c}0.1436 \\
(0.1115)\end{array}$ \\
\hline $\begin{array}{l}\text { Slate law gives the Slate the power to assess county } \\
\text { property taxes }\end{array}$ & $\begin{array}{l}0.0330 \\
(0.0276)\end{array}$ & $\begin{array}{l}-0.2637 \\
(0.0855)\end{array}$ \\
\hline $\begin{array}{l}\text { State's "Rainy Day Fund" as a percentage of State's } \\
\text { lotal expenditures in } 1987\end{array}$ & $\begin{array}{l}-0.0026^{b} \\
(0.0012)\end{array}$ & $\begin{array}{l}0.0044 \\
(0.0036)\end{array}$ \\
\hline County belongs to a Regional Organization & $\begin{array}{l}0.0224^{h} \\
(0.0114)\end{array}$ & $\begin{array}{l}-0.0585 \\
(0.0393)\end{array}$ \\
\hline Fraclion of eounty population living in municipalitics & $\begin{array}{r}0.0515^{c} \\
(0.0296)\end{array}$ & $\begin{array}{l}-0.0058 \\
(0.1171)\end{array}$ \\
\hline County Controls & yes & yes \\
\hline Stalc Controls & yes & yes \\
\hline Service dummies & yes & yes \\
\hline Region dummics & yes & yes \\
\hline Number of Observations & 4,290 & 991 \\
\hline Log Likelihood & -1518 & -594 \\
\hline Pseudo $\mathbf{R}^{2}$ & .0473 & .0852 \\
\hline
\end{tabular}


Appendix A

Summary Statistics of Variables

Summary statisties for the population of 3,042 Counties in the United States

\begin{tabular}{|c|c|c|c|c|c|c|}
\hline Variable & Obs. & Mcan & Median & Std. Dev. & Minimum & Maximu \\
\hline $\begin{array}{l}\text { Wage Premium of county employees over } \\
\text { private sector employees }\end{array}$ & 3042 & 1.1541 & 1.1072 & 0.3586 & 0.2128 & 4.370 \\
\hline $\begin{array}{l}\text { Fraction of County government employees } \\
\text { represented by bargaining units }\end{array}$ & 3036 & 0.0948 & 0 & 0.2103 & 0 & 0.991 \\
\hline $\begin{array}{l}\text { Equivalent Full time county government } \\
\text { employees per } 1000 \text { inhabitants }\end{array}$ & 3042 & 10.196 & 6.9405 & 10.8039 & 0 & 288.65 \\
\hline Slate law requires merit system for county & 3042 & 0.3418 & 0 & 0.4744 & 0 & 1 \\
\hline State law allows county employces to strike & 3042 & 0.0506 & 0 & 0.2192 & 0 & 1 \\
\hline $\begin{array}{l}\text { State law forbids county employees to } \\
\text { engage in political activity }\end{array}$ & 3042 & 0.4494 & 0 & 0.1859 & 0 & 1 \\
\hline $\begin{array}{l}\text { Fraction of gubernatorial votes for } \\
\text { Republican candidate }\end{array}$ & 3042 & 0.4704 & 0.4834 & 0.1473 & 0.0323 & 0.833 \\
\hline $\begin{array}{l}\text { State law authorizes counties to have } \\
\text { short-term borrowing }\end{array}$ & 3042 & 0.6180 & 1 & 0.4859 & 0 & 1 \\
\hline $\begin{array}{l}\text { State law sets purchasing standards for } \\
\text { countics (type of auction and preferences) }\end{array}$ & 3042 & 0.7870 & 1 & 0.4095 & 0 & 1 \\
\hline State law imposes debt limits on countics & 3042 & 0.7765 & 1 & 0.4166 & 0 & 1 \\
\hline $\begin{array}{l}\text { State constitution or statutory law mandates } \\
\text { a balanced budget for counties }\end{array}$ & 3042 & 0.2158 & 0 & 0.4114 & 0 & 1 \\
\hline $\begin{array}{l}\text { State law allows that State may take over } \\
\text { the financial administration of county }\end{array}$ & 3042 & 0.0559 & 0 & 0.2297 & 0 & 1 \\
\hline $\begin{array}{l}\text { State law gives the State the power to } \\
\text { assess county property taxes }\end{array}$ & 3042 & 0.0746 & 0 & 0.2628 & 0 & 1 \\
\hline $\begin{array}{l}\text { State "Rainy day fund" in } 1987 \text { as a } \\
\text { percentage of State government's total } \\
\text { cxpenditures. }\end{array}$ & 3042 & 3.3302 & 3.29 & 6.3076 & -11.72 & 41.27 \\
\hline Unemployment rate in the county in 1986 & 3041 & 0.0875 & 0.0790 & 0.0412 & 0.018 & 0.379 \\
\hline $\begin{array}{l}\text { Fraction of county population living in } \\
\text { municipalities in } 1987\end{array}$ & 3042 & 0.4685 & 0.4792 & 0.2128 & 0 & 1 \\
\hline County belongs to a Regional Organization & 3040 & 0.6615 & 1 & 0.4733 & 0 & 1 \\
\hline Resident Population in the county in 1987 & 3042 & 72.205 .1 & 22,300 & $247,539.8$ & 100 & $8,481,5$ \\
\hline $\begin{array}{l}\text { Population per square mile of land in the } \\
\text { county in } 1987 \text { (in thousands) }\end{array}$ & 3042 & 1.2283 & 0.3728 & 4.1282 & 0.0006 & 117.17 \\
\hline $\begin{array}{l}\text { Bank Deposits per capita in the county in } \\
1987\end{array}$ & 3020 & $7,032.7$ & $6,429.2$ & $3,336.2$ & 0 & 38,027 \\
\hline $\begin{array}{l}\text { Personal Per capita lncome in the county in } \\
1987\end{array}$ & 3013 & $12,410.35$ & 12,173 & 2880.213 & 4,033 & 30,46 \\
\hline $\begin{array}{l}\text { Percentage of the county's population } \\
\text { above } 25 \text { ycars old with at least high school } \\
\text { degree }\end{array}$ & 3042 & 0.6961 & 0.7137 & 0.1038 & 0.3156 & 0.989 \\
\hline Resident Population in the State in 1987 & 3042 & $6,434,280$ & $4,807,000$ & $5,579,408$ & 490,000 & $27,700,0$ \\
\hline $\begin{array}{l}\text { Bank Deposits per capita in the State in } \\
1987\end{array}$ & 3042 & 7.7124 & 7.2004 & 2.2411 & 3.8617 & 28.325 \\
\hline $\begin{array}{l}\text { Personal Per capita Income in the State in } \\
1987\end{array}$ & 3042 & $14,078.61$ & 14,008 & $1,884.04$ & 10,318 & 20,34 \\
\hline State Unemployment rate in 1986 & 3042 & 0.0739 & 0.0700 & 0.0196 & 0.028 & 0.131 \\
\hline $\begin{array}{l}\text { Percentage of the state's population above } \\
25 \text { years old with at least high school } \\
\text { degree }\end{array}$ & 3042 & 0.7469 & 0.7516 & 0.0553 & 0.6428 & 0.866 \\
\hline
\end{tabular}

